\title{
Organizational Capital, Production Factor Resources, and Relative Firm Size in Strategic Equity Alliances
}

This is the author's accepted manuscript version of an article published in:

Belgraver, H., \& Verwaal, E. (2018). Organizational capital, production factor resources, and relative firm size in strategic equity alliances. Small Business Economics, 50(4), 825-849. doi:

10.1007/s11187-017-9897-z

The final publication is available at Springer via http://dx.doi.org/ 10.1007/s11187-0179897-z

\author{
Herman Belgraver* \\ Faculty of Economics and Business \\ KU Leuven \\ Korte Nieuwstraat 33 \\ B-2000, Antwerpen \\ Tel: +32 (0) 32011887 \\ E-mail: herman.belgraver@kuleuven.be
}

Ernst Verwaal

Faculty of Economics and Business

KU Leuven

Korte Nieuwstraat 33

B-2000, Antwerpen

Tel: +32 (0) 468232900

E-mail: ernst.verwaal@kuleuven.be

Keywords: Relative Firm Size, Alliances Resources, Contingent Resource-Based View, Production Factor Resources, Organizational Capital, Firm Financial Performance

JEL Classifications: L1, L2, L86, M1, M2, O33, D23

* Corresponding author 
The final publication is available at Springer via http://dx.doi.org/ 10.1007/s11187-017-9897-z

\title{
Organizational Capital, Production Factor Resources, and Relative Firm Size in Strategic Equity Alliances
}

\begin{abstract}
Access to complementary resources through strategic equity alliance networks is an important activity for both smaller and larger firms. In the literature, there is an intensive debate on the impact of alliance resources for smaller firms. We submit that the effect of alliance resources on the smaller firm financial performance depends on the attributes of these resources. Specifically, we argue that the attributes of partner organizational capital are negatively related and the attributes of partner production factor resources are positively related to the smaller firm financial performance. We test our theoretical framework by applying a longitudinal analysis to a dataset of 1,730 firm-year observations of strategic equity alliances in the software industry in 25 countries over an 11-year period. We find support for our hypotheses, highlighting the critical importance of resource attributes for smaller firms in strategic equity alliance networks.
\end{abstract}




\section{Introduction}

Entrepreneurial firms can be characterized by their innovation and growth ambitions (Stevenson \& Jarillo 1990; Stevenson \& Jarrillo-Mossi 1986; Moreno \& Casillas 2008); however, they often lack the necessary resources to accommodate these ambitions (Jarillo 1989; Eisenhardt \& Schoonhoven 1996). Therefore, smaller entrepreneurial firms are often searching for opportunities to acquire or access complementary resources (Jarillo 1989; Lechner \& Dowling 2003). Strategic alliances can be instrumental to smaller firms to gain access to such complementary resources from larger partner firms (Parkhe 1991; Inkpen 1998), and can be based on equity or non-equity alliance governance modes.

In this study, we focus on strategic equity alliances (SEAs), because these alliances are associated with a long-term commitment to an exchange relationship between partner firms. In contrast, non-equity alliances are in general well-defined and specific to a certain activity or task, which makes them less likely to be associated with entrepreneurial resources that can be used for multiple purposes (Ellis 2011, pp. 290-291). Furthermore, SEAs are used under conditions where the appropriation risks are high (Oxley 1997; Pisano 1989; Gulati \& Singh 1998), the end-product is difficult to specify (Oxley 1997), or the scale and scope of the activities are ambiguous. Finally, SEAs are alliance relationships that build on credible commitments while leaving intact an incentive structure for entrepreneurial behavior (Grossman \& Hart 1986; Williamson 2008).

In this paper, we will analyze the position of the smaller entrepreneurial firm in SEA networks. Previous research has documented numerous benefits of SEAs for the smaller entrepreneurial firm, including the ability to tap into new markets (Shan \& Hamilton 1991); have access to economies of scale (Ireland et al. 2002; Hertz \& Alfredsson 2003; Makadok 2001); benefit from technology or knowledge exchanges (Meier 2011; Al-Laham et al. 2010); overcome trade barriers (Shan \& Hamilton 1991); and receive endorsements from reputable incumbents (Greenwood et al. 2005; Stuart et al. 1999). Despite these reported benefits, there is extensive debate in the literature about whether the combined resources from different firms in an entrepreneurial network always lead to positive outcomes for the smaller firm. Smaller firms are also more likely to lack sufficient access to production factor resources (Kalaignanam et al. 2007; Bercovitz \& Mitchell 2007; Eisenhardt \& Schoonhoven 1996), and therefore may benefit more from access to production factor resources (PFRs) from larger SEA partners. Larger firms, on the other hand, may gain from access to a variety of organizational capabilities (OC) that allows them to better deal with 
uncertainty (Alvarez \& Barney 2001; Larson 1991; Acs et al. 1997). This may improve their capacity to handle change in the business environment. Therefore, the size differential in the SEA may explain different needs and effects of using complementary partner resources. In addition, the relative size is an indicator of the difference in absorptive capacity (Fiol \& Lyles 1985; Zahra \& George 2002; Lane \& Lubatkin 1998) and herewith the ability to benefit from the partners' resources.

Gander et al. (2007) investigated alliances between major music companies and independent smaller partners, and they suggest that the attributes of resources or their function may change if they are put into another context. They suggest that certain resource attributes may even become hostile and may potentially negatively affect the firm's financial performance. This study uses the findings of Gander et al. (2007) as starting point to empirically investigate the financial performance effects of partner firms' resources in the context of smaller and larger partner firms. Lane and Lubatkin (1998) have argued in an alliance the degree of interfirm learning (relative absorptive capacity) depends on the similarity of the knowledge base both firms. In this study, we explore how relative firm size related differences in de organizational knowledge base may promote or hinder the financial firm performance of the smaller or large firm.

In the literature, scholars often use the arguments for the strongly related concepts of absolute firm size and relative firm size loosely. In our definition of relative firms' size, a relative size argument is dependent on the size of the partner and an absolute size argument is not. This means that we classify structure as an absolute size argument because the arguments of structure are independent of the size of the partner firm. Knowledge scale and scope arguments are relative size arguments because their effect depends on the size of the partner relative to the focal firm.

One possible source of these differences may be related to the partner OC and partner PFRs. OC refers to the organizational capacity of firms to generate rents from PFRs (Amit \& Schoemaker 1993; Makadok 2001), whereas PFRs refer to inputs into a firm's transformation process, such as labor, finished components, and raw materials. In other words, $\mathrm{OC}$ is the agglomeration of technologies, business practices, processes, and designs that enables firms to add value to PFRs (Lev et al. 2009). In this paper, we will argue that the high task interdependence of partner OC creates unique problems (Thompson 1967), which explains why access to partner OC in SEAs has a different effect on the financial performance for smaller and larger firms in SEA networks. PFRs involve encoded knowledge and are, in general, context-free (Cheng 2004), whereas OC involves embedded knowledge and, in 
general, is context-bound and tacit to a high degree (Boyd et al. 1993). In this paper, we will explore if the extent to which complementary resources are encoded and context-free may have a different impact on their transferability and integration into the smaller firm as compared to the larger firms.

The paper proceeds as follows: first, we provide a theoretical background and explain the theoretical underpinnings of its hypotheses. We address the different types of complementary resources and subsequently focus on those resources that are of importance in entrepreneurial networks consisting of smaller and larger firms. Next, we present the data and explain the methodology. We test the proposed theoretical framework by using a database of 1,730 unique SEA relationships in the software industry in 25 countries over 11 years. We use the software industry because it is an industry with multiple dimensions that can be best characterized in terms of the degree of codification of knowledge. Some parts of the software industry have strong similarities and links with the creative industries, because its products also create a rational addiction, and both are dependent on (technological) innovation for their speed of diffusion among the consuming public (Caves 2000). We find for smaller firms a negative financial performance effect of partner $\mathrm{OC}$ and a positive financial performance effect of partner PFRs, and that these financial performance effects are reversed for larger firms. Our results therefore reveal that specific partner resource attributes explain why entrepreneurial networks provide opportunities or threats to smaller firm. The paper concludes with a discussion of the study's limitations, the implications for managers, and suggestions for further research on the role of different partner resources in entrepreneurial networks.

\section{Literature review and hypotheses}

\subsection{Organizational capital and production factor resources}

The term "resources" covers a broad spectrum of activities and objects. The specialization of these resources is "a necessary condition for rents" (Amit \& Schoemaker 1993, p. 39; Mudambi \& Tallman 2010, p. 1441) and comes with many different attributes (Hitt \& Ireland 1986; Newbert 2007) that can help or hinder the firm in employing valuable strategies. As indicated in the introduction, the term "resources" can refer to PFRs and to the OC that allows the focal firm to generate rents from these resources (Amit \& Schoemaker 1993; Makadok 2001). OC generates rents through a form of "capability-building mechanism" (Makadok 2001). Capability building 
consists of organizational processes that are deployed to enhance the value of PFRs (Amit \& Schoemaker 1993). These processes are organization-context specific and cannot easily be transferred between organizations (Teece et al. 1997). Organizational capabilities are embedded in bundles of interrelated routines that represent organizations' knowledge and experience (Aaltonen \& Lanzara 2015). The OC that creates value from PFRs and is embedded in organizational processes, managerial processes, and structures, and is considered interdependent and therefore difficult to transfer to other organizations (Alvarez \& Busenitz 2001; Khoury \& Pleggenkuhle-Miles 2011).

PFRs provide economic rents through a form of a "resource-picking mechanism" (Makadok 2001, pp. 387388). Resource-picking consists of selecting valuable resources and outsmarting the competition in picking these resources (Barney 1986). Firms can create value by acquiring a PFR under their productive value from an alliance partner because they may have private information about valuable resource combinations to which they have exclusive access (Makadok 2001; Barney 1986). Managers with superior resource-picking skills can create economic rents before the acquisition of specific PFRs (Makadok 2001). Thus, PFRs distinguish themselves from $\mathrm{OC}$ in that there are more cognitive and informational factors involved in the resource-picking mechanism and more structural factors in the capability-building mechanism (Makadok 2001). The resource-picking mechanism depends on a rational evaluation of the resources (Makadok 2002). PFRs as discrete resources can be valued in advance, and firms are assumed to obtain them at a quantity where their marginal cost equals their benefits (Miller \& Shamsie 1996). PFRs provide the focal firm with a high degree of control and value under conditions of low environmental change (Miller \& Shamsie 1996).

In this study, we define the "focal firm" in line with social network theory (Wasserman \& Faust 1994; Borgatti \& Halgin 2011; Uzzi 1996; Rowley et al. 2000; Uzzi 1997; Ahuja 2000; Granovetter 1983; 1973; Burt 1992). The tie between ego and alter does not indicate any information about the type of relation or the characteristics of the alters in the ego-centered network. Therefore, in ego-centered network analysis, additional tieand alter-related information must be collected in order to analyze the relational characteristics (Wasserman \& Faust 1994, pp. 53-54). Next we focus on the partner OC and its potential impact on the focal firm financial performance.

\subsection{Partner organizational capital and focal firm financial performance}

OC often requires more complex and implicit communication and integration of cognitive and behavioral frameworks (Griffin \& Hauser 1996; Dougherty 1992). Dyer and Nobeoka (2000) have illustrated in their study of 
the Toyota network how the understanding of specific organizational routines is difficult and time consuming because of their tacit nature and because they are rooted in the cultural values and norms of the organization (Dyer \& Nobeoka 2000). Thus, seemingly complementary organizational resources can become inimical to the new context they are used in (Gander et al. 2007; Gander \& Rieple 2002; Campbell et al. 1995) and may act as a "poison pill" in the resource base of a partner.

Organizational capabilities contain embedded regulative components and rule-driven behavior that governs the interrelated organizational routines (Dosi et al. 2008; Aaltonen \& Lanzara 2015). Examples of these resources are an integrated supply, manufacturing, and distribution system. Organizational capabilities consist of systems of interrelated and interacting assets and routines (Lev et al. 2009). This system needs a mechanism of governing routines to coordinate the system's different subroutines (Aaltonen \& Lanzara 2015; Dosi et al. 2008); such governing routines are deeply embedded in the system of routines and are difficult to distinguish from problemsolving routines (Aaltonen \& Lanzara 2015). In contrast to discrete resources, firms should aim to "enhance the range of and comprehensiveness of a pre-existing system" (Miller \& Shamsie 1996, p. 525). These should not be substitutes but complementary to the existing resources, because these systemic resources can be applied in varying conditions and may be useful in adapting to changing environments (Miller \& Shamsie 1996). It is very difficult to pick and choose organizational capabilities from an alliance partner and connect these to the focal firm organization, because the system of organizational routines (Aaltonen \& Lanzara 2015; Pentland \& Feldman 2005) has uniquely evolved over time and therefore can be incompatible with the routines of the partner firm.

Argyres et al. (2012) argue that "firms know more than what they can communicate in a cost-efficient manner across their organizational boundaries" (Argyres et al. 2012, p. 1219). As a hybrid governance form, an SEA may be insufficient for embedding organizational routines because firms differ in their heterogeneous bundles of resources and the unique patterns of their complementarity of resources (Argyres et al. 2012). Moreover, a lack of goal alignment (Hennart \& Zeng 2005) between firms may cause sub-optimal resource combinations (Das \& Teng 2000). Joint decision-making between alliance partners means they are "virtually guaranteed to clash on occasion" (Park \& Russo 1996, p. 879), as their shared resources, especially organizational routines, need to be complementary for both organizational contexts. The unique context-embeddedness of organizational resources may therefore create a sub-optimal combination between the resources of the partners. Thus, we hypothesize as follows:

Hypothesis 1a. Access to partner organizational capital has a negative effect on the focal firm's financial 
performance.

\subsection{Relative firm size and the exchange of organizational capital}

In this study, we investigated the contingent effect of the relative firm size rather than the absolute size, because in alliance networks, the relative size of the partners is more informative about the relation and resource contributions than the absolute firm size. As argued by Gomes-Casseres (1997, p. 34), "Relative size is a key factor behind any firm's alliance strategy, regardless of their absolute size.". Size is a context dependent measure - what is classified in the context of one industry as a larger firm is classified as a smaller firm in another industry (Gomes-Casseres 1997). Furthermore, the size advantage of a firm depends on the environment in which it operates, the control it can exert on the alliance partners, and the capabilities the alliance can offer the focal firm (Gomes-Casseres 1997). Relative firm size is extensively studied in the literature on mergers and stock market performance. According to the "relative size hypothesis" (Merchant \& Schendel 2000), smaller firms have higher abnormal returns than larger firms during an alliance announcement. However, studies that investigate the "relative size hypothesis" report conflicting results. Koh and Venkatraman (1991) and Das et al. (1998) found that smaller alliance partners benefit more from an alliance than larger alliance partners. In contrast, McConnell and Nantell (1985) found that, in an alliance, both partners (smaller and larger) experience a similar value creation (Merchant \& Schendel 2000).

The causes of these conflicting results are mainly attributed to organizational differences between smaller and larger firms. Lane and Beamish (1990) and Killing (1983) have suggested that a size differential can cause problems concerning the time-orientation of the alliance partners. Larger firms tend to have systematically slow decision-making systems and have, in general, a long-term investment orientation. In contrast, smaller (entrepreneurial) firms tend to have quicker intuitive decision-making systems and have a short-term investment orientation. Smaller firms generally have more pressing financial needs. Park and Ungson (1997) and Merchant and Schendel (2000) argued that size differentials may lead to different corporate perspectives, values systems, and alignment methods of internal resources (Park \& Ungson 1997), and that these differences can have a negative effect on financial performance.

To benefit from the partner's OC, a firm needs the ability to integrate it. A major component of OC is a broad and complex range of knowledge. The transfer of complex knowledge resources is easier for the partner with a longer time horizon (Hansen 1999; Zander \& Kogut 1995; Tua 2000), more organizational slack (Nohria \& Gulati 
1997), and a broader range of expertise (Grant 1996a; b). Partners with these capabilities are better equipped to acquire the broad domain of knowledge encapsulated in the partner firm's organizational capital. This suggests that the larger firm is more suited to integrate organizational knowledge than the smaller partner firm (Grant 1996b; Kale et al. 2002).

The impact of a technological innovation is often felt in other industries than those for which it was initially developed (Rosenberg 1982; 1994). That is, the smaller partner may have less options to apply knowledge developed by the larger partner firm in one industry and may apply it in another industry. Smaller firms can less easily deploy knowledge-intensive business services, which create, collect, and disseminate knowledge to provide their (internal) customers with tailor-made service solutions. Specialized knowledge brokers give larger firms a strategic advantage by providing access to knowledge from different industries (Schilling \& Phelps 2007; Hargadon 1998); larger firms benefit from this network position by learning from a wide variety of existing problems and solutions and leveraging them in different combinations of this knowledge (Hargadon 1998; Nerkar 2003; Katila \& Ahuja 2002). These knowledge brokers may also act as boundary-spanners between the focal firm and the alliance partner (Kale et al. 2002; Schreiner et al. 2009).

Smaller firms, through their smaller knowledge base, can less easily integrate and apply the OC of the larger alliance partners and thereby benefit less from their innovative organizational routines (Sarkar et al. 2001) or innovation and entrepreneurship (Barringer \& Harrison 2000; Fisher 1996). Although, in general, partner OC negatively affects focal firm financial performance, smaller firms are less likely to generate rents from access to the organizational routines compared to their larger partner firms. This leads us to the following hypothesis:

Hypothesis 1b. The negative impact of access to partner organizational capital on the focal firm's financial performance is positively moderated by the relative size of the focal firm.

\subsection{Production factor resources and focal firm financial performance}

PFRs are used to expand the scale and scope of the firm's operations and are critical determinants of the reduction of average and cumulative costs of production. Scaling-up of their operations is critical for smaller entrepreneurial firms and this requires PFRs, such as labor and financial resources (Mishina et al. 2004, pp. 11831184). To deploy these PFRs in an operational capacity is a complex strategic capability (West III \& Bernhardt 2009; Youndt et al. 1996; Winter \& Szulanski 2001). As indicated in the background discussion, PFRs are generally 
more easily valued and are mainly in the form of labor (Neffke \& Henning 2013) and financial (Laitner 2000) resources that can be deployed in upscaling the activities of the partner firms in the SEA. Labor resources are a means of upscaling a firm's market expansion, and can be considered as the more restricted form of PFRs, because the decision-makers in a firm must anticipate future resource requirements (Mishina et al. 2004). Labor resources are considered "sticky" (Mishina et al. 2004, pp. 1183-1184) because of their path-dependent, time-compression diseconomies (Stevens \& Shenkar 2012; Dierickx \& Cool 1989) and the inert nature of human resources (Hannan \& Freeman 1984).

Financial resources are generally considered more flexible than labor resources because they can be transformed into other upscaling resources (Mishina et al. 2004). Financial resources can be considered upscaling resources for product expansion, as they can be adapted to growth opportunities in the quickly changing and unpredictable marketplace (Mishina et al. 2004), but a firm having more financial resources than it needs is also perceived as a sign of a lack of efficiency or growth opportunities (Mishina et al. 2004). In addition, cash and shortterm investments have, in general, a lower return or interest rate than investments in operational activities (Jensen 1986; Shin \& Kim 2002; Stulz 1990). Both financial and labor resources are needed for a firm to grow, but they are difficult to acquire in the short term if the firm does not possess them, and may rapidly depreciate if it does not use them (Rubb 2006). An example of human capital depreciation can be found in the study by Mincer and Polachek (1974). One may assume that capacity surplus or shortages can easily be managed by using the market mechanism; however, in practice efficient markets for financial and labor resources are rarely observed. Therefore, the benefits of access to production-factor (labor and financial) resources through equity alliances may be substantial, as firms may not be able to own or control access to these production factors at the desired levels. The social network of SEA partners, underlined by an equity investment, increases the access to partner resources compared to market partners. Thus, in contrast to the OC, gaining access to the equity alliance partner's PFRs is likely to create value for the focal firm. This leads us to the following hypothesis:

Hypothesis $2 \boldsymbol{a}$ and $2 \boldsymbol{b}$. Access to the partner (a) financial and (b) labor production factor resources has a positive effect on a focal firm's financial performance.

\subsection{Relative firm size and the exchange of production factor resources}

As previously argued, PFRs are used to expand the scale and scope of the firm's operations and are critical 
determinants of the reduction of average and cumulative costs of production. Smaller firms have, in general, a higher need for PFRs because of their smaller access to scale and scope advantages. But when a smaller firm forms an alliance with a larger firm, there can be advantages and disadvantages.

Osborn and Baughn (1990) argued that smaller firms may be comparatively vulnerable because of a lack of slack resources, limited technical cores, a lack of retaliation resources, weak links with government, weaker reputation, and perhaps being more vulnerable to the exploitation of alliance partners (Park \& Kim 1997; Park \& Ungson 1997). Furthermore, smaller firms may be more concerned with tactical positioning or technological adjustments that govern the transaction cost of one alliance and less concerned with their global strategic positioning (Osborn \& Baughn 1990). Shan and Hamilton (1991) argued that smaller firms have less global scanning capabilities and are, in general, confined to a limited number of markets. Moreover, Rosenbusch et al. (2011) argued that smaller firms lack the expertise of managing an alliance and lack the slack to absorb failures.

Katila et al. (2008) investigated the benefits and risks that smaller firms face when they ally themselves with larger firms. Katila et al. (2008) called the trade-off between the attractiveness of resources and the risk of misappropriation the "sharks dilemma". They argue that smaller firms still ally with larger firms despite the risk of misappropriation when the trade-off between benefits and risks is acceptable. Smaller firms do not, in general, have the resources for protecting patents, which are difficult to obtain and require specialized resources. But smaller firms can make use of their trade secrecy and timing options. The obtaining of trade secrets has a much lower threshold, and the timing defense option gives the alliance partner knowledge resources at upfront agreed times or phases in the alliance. This increases the control of the smaller partner in the alliance and limits the risks of misappropriation.

In contrast, the benefits of forming an alliance with a larger partner can be significant. Equity alliances may offer smaller firms access to PFRs possessed by partners, which offers them the prospect of offsetting their scale and scope disadvantages (Sarkar et al. 2001). Larger firms can provide the smaller firm with the necessary cash resources to underwrite new investments and ride out demand downturns, as well as access to the supply chain advantages necessary to optimize efficiency (Burgers et al. 1993). When a smaller firm collaborates with a larger partner, the revenue potential of the equity alliance is likely to be significant because the smaller partner is tied into a larger revenue stream. In the case of an R\&D alliance, the smaller firm can benefit from the larger firm's scaleand-scope economies, thus reducing the technological and financial risks. Therefore, partnerships with better connected and better endowed larger firms offer smaller firms greater rewards than equity alliances with business 
associates that lack these resources (Stuart 2000). Smaller firms in equity alliances can also increase demand economies of scale and benefit from improved legitimacy through partnerships with their larger reputable partner firms (Barringer \& Harrison 2000; Roberts \& Dowling 2002; Stuart 2000). The more access smaller firms have to SEAs with larger firms, the more they can benefit from partner PFRs because they tend to gain more from access to PFRs than do larger firms (Das et al. 1998). Therefore, smaller firms are likely to generate more rents from access to partner PFRs compared to larger firms that have more access to these resources. This leads us to the following hypothesis:

Hypothesis $2 c$ and $2 d$. The positive impact of access to the partner's (c) financial and (d) labor production factor resources on the focal firm's financial performance is negatively moderated by the relative size of the focal firm.

\section{Methodology}

\subsection{Data}

The data used for this study was collected from a sample of publicly traded focal firms operating in the software (US SIC 7370) industry. The software industry has a high environmental uncertainty due to expiring patents, increasing R\&D cost, long innovation developing times, and a high degree of innovative erosion. SEAs are a means of increasing productivity, filling the new product development pipeline, and achieving a continuous stream of innovations. High environmental uncertainty and technological disruptions are more the norm than the exception in the software industry (Nidumolu \& Subramani 2003). In these kinds of uncertain situations, firms tend to use SEAs to gather information and to gain access to critical resources (Peng \& Heath 1996; Marino et al. 2008; Tallman \& Shenkar 1994; Eisenhardt \& Schoonhoven 1996). However, the software industry is a multi-dimensional and diffused industry (Caves 2000; Campbell-Kelly 2004), which uses technological, cultural, social (Aoyama \& Izushi 2003), and existing knowledge in creating products and services (Mehta 2008). The software industry is a complex industry that differs from industries like manufacturing because it makes use of a relatively large part of tacit knowledge, it depends on interdependent professional decisions on all levels, and it develops with the life cycle of the project, from craftsmanship to engineering (Rus \& Lindvall 2002). Thus, although the software industry is not a singular industry, it is most likely an industry in which resource exchange with knowledge resources will occur. 
For this study, we constructed a dataset from the following sources: The equity alliance data was downloaded from the Zephyr database (Bureau van Dijk) and checked with the Securities Data Company (SDC) (Thomson Reuters) database; if there were differences between the Zephyr and SDC databases, an additional check in the Factiva database was performed and the research database was corrected accordingly. Firm-level financial data was downloaded from the Worldscope database (Thomson Reuters).

The database required financial data from both SEA partners because we need to control for the resources of the focal and partner firms. Therefore, only deals in which both partners were listed on a stock exchange were selected (Pisano 1989). The firm's financial data was downloaded from the Worldscope database (Thomson Reuters). We linked the two datasets via the International Securities Identifying Number (ISIN). The financial data was centered on the SEA deal announcement year. The constructed dataset started at year zero (deal announcement year) and ended five years after the deal announcement year. These SEAs spanned a period of 11 years, from 1996 to 2006 .

We filtered out the outliers for both the focal firm and the partner firm for firms with a return on assets (ROA) smaller than -2 and larger than +2 because the ROA was sensitive to outliers due to firms having a small number of assets. By using this filter technique, we imposed a limitation on the dataset where we only used those alliances in which we had access to the financial performance data of both the focal firm and the partner firm. To control for country effects, we imposed, in accordance with the central limit theorem, a limitation of at least five cases per country. This resulted in a software industry database of 393 SEAs over 11 years, consisting of 181 joint ventures and 212 minority investments deals. We included the following 25 countries in the analysis: Australia, Austria, Bermuda, Canada, the Cayman Islands, China, Finland, France, Germany, Greece, India, Israel, Italy, Japan, the Republic of Korea, Malaysia, Netherlands, Norway, Poland, Portugal, Singapore, Sweden, Taiwan, the United Kingdom, and the United States of America. We controlled for country effects via country dummy variables. We controlled for conjuncture and exogenous shocks via year dummy variables, and these year dummy variables were created for each alliance announcement year between 1996 and 2006. The database was a mix of single and multiple partner deals, and all multiple partner deals were transformed into dyadic deals. We controlled for differences between single and multiple partner deals via the dummy variable multi-partner partnerships and via the variable focal firm number of partners. The cross-sectional database was transformed into a longitudinal database over a period of six years, including the year of the equity alliance announcement. This resulted in a software 
database of 2,369 firm-year observations over 11 years, 1,418 joint ventures, and 951 minority investments firmyear observations.

\subsection{Variables}

In this section, we present the variables used in the analysis. The descriptive statistics, including the mean, standard deviations, and list-wise correlations between the variables, are to be found in Table 1, and the regression results of the hierarchical linear fixed effects model (HLM) are contained in Table 2. All continuous variables, except the relative focal firm profitability and relative focal firm size, were natural log transformed to ensure that independence, linearity, and the homoscedastic properties were maintained (Stuart 2000). All continuous variables, except the dependent variable, were standardized to remove the nonessential multicollinearity (scaling effect, nonzero mean) (Cohen et al. 2003; Marquardt 1980; Marquardt \& Snee 1975). All these variables were measured longitudinally over a period of six years, except for the dummy variables. The relative focal firm profitability and relative focal firm size were standardized but not natural log transformed, because this transformation would eliminate values smaller or equal to zero.

\subsubsection{Firm financial performance}

The economics and management literature has widely recognized that firms may have multidimensional goals, but also noted that the firm is primarily concerned with financial results (Goerzen \& Beamish 2005) because financial measures are essential indicators of its viability. In the literature, return on assets, return on sales, sales growth, return on capital, and market value are the most widely accepted measures. We chose the return on assets (ROA) measure because we are interested in the value appropriation capacity of the focal firm. ROA is a measure of firm profitability that this study used as a measure of firm financial performance. The ROA is calculated by dividing the earnings before interest and taxes (EBIT) by the firm's total assets for each observation year. It is an accountingbased indicator that is considered better than return on equity (ROE) because ROE is affected by capital structure as well as operational efficiency (Kim et al. 2004).

\subsubsection{Organizational capital}


$\mathrm{OC}$ is the total of the unique organizational resources that can generate sustainable competitive advantages due to their path dependency (Eisenhardt \& Martin 2000; Dierickx \& Cool 1989), tacit nature (Berman et al. 2002), causal ambiguity (Alvarez \& Busenitz 2001; King 2007), and production factor resource-enhancing abilities (Marino et al. 2008). As argued and empirically demonstrated by Lev et al. (2009), OC can be measured by the partner firm's annual selling, general and administrative (SGA) investments (Lev et al. 2009). The "firm's SGA expenses include outlays related to the building of organization capital, such as information systems, employee training, research and development, consultants' fees, and brand promotion" (Lev et al. 2009, p. 279). These are the indirect costs of an organization not directly attributable to the production process. Lev et al. (2009) showed that SGA expenses can be used as an instrumental variable in explaining the financial performance effects of OC. Following the seminal article by Lev et al. (2009), this study measures OC by the annual SGA investments. In contrast to the methodology of Lev et al. (2009), many studies in the economic and management literature still use a perceptual measurement of OC (e.g. (Hsu 2007; Subramaniam \& Youndt 2005; Carmona-Lavado et al. 2010)). The risk associated with the use of perceptual items is that they may lead to a subjective measure of OC by organizational members or key informants (Boyd et al. 1993). Perceptual measurements have limited generalizability, and reliability and validity problems, which can lead to erroneous empirical results and interpretations (Boyd et al. 1993). In addition, the analysis method that is often used when analyzing perceptual data is the squared error statistical technique. This technique needs very large samples to ensure a reliable analysis (Starbuck \& Mezias 1996). Therefore, this study used the validated instrumental (SGA) variable, which was developed and empirically validated by Lev et al. (2009), to ensure the reliability and validity of this measurement. To reduce the risks of multicollinearity, the partner firm OC variable is normalized by dividing the partner firm OC by the partner firm sales.

\subsubsection{Production factor resources}

PFRs are measured as the financial and labor production factor resources available to a firm. A financial PFR is measured by the partner firm's annual cash and short-term investments (Schumpeter 1954). A labor PFR is measured by the partner's annual total number of employees (Schumpeter 1954). Due to size effects and the risk of multicollinearity, only the partner firm financial PFR is normalized by dividing it by the partner firm sales. The partner firm labor PFR variable was only standardized but not divided by partner firm sales due to collinearity with the focal firm relative size variable. 


\subsubsection{Relative firm size}

The variable of relative focal firm size refers to the size of the focal firm relative to the size of its partner in the dyadic equity alliance relationship. The relative focal firm size is calculated by the difference between the number of focal firm employees and the partner firm employees (numerator). The theoretical arguments with respect to size are related to the specialization of human resources in larger firms (Verwaal \& Donkers 2003). In the software industry, measuring relative size by total assets is less reliable because specialization depends more on the size of the labor pool than on other assets. The difference in the number of employees has a non-arbitrary, unique, and meaningful zero point. Positive values imply that the focal firm has more employees than the partner firm; in contrast, negative values imply that the partner firm has more employees. The numerator is highly sensitive to the absolute size of the equity alliance partners; a small size difference between larger firms can show as equal to the size difference between a larger and a smaller firm. Therefore, this study deflated the numerator with the sum of the focal firm and the partner firm total number of employees. This creates a meaningful measure that always stays between -1 and +1 .

\subsection{Control variables}

\subsubsection{Bargaining power}

Bargaining power is the capability to favorably negotiate the terms and influence the outcomes of agreements (Yan \& Gray 1994). A source of bargaining power is the dependence or interdependence that the equity alliance partners have relative to one other (Pfeffer \& Salancik 1978), and this is reflected by how rents are divided among the equity alliance partners (Porter 1985) and the number of alternatives available to the focal firm (Bacharach \& Lawler 1981).

We used two measures to measure the relative focal firm bargaining power - relative focal firm profitability and focal firm relative alternatives. Relative focal firm profitability (relative economic strength) measures the difference between the ROA of the focal firm and the partner firm. The ROA is calculated by dividing the earnings before interest and taxes (EBIT) by the firm's total assets for each observation year. Higher values suggest that the focal firm is less dependent on the outcome of the equity alliance and thus enjoys greater bargaining power. The relative alternative measures the focal firm's structural dependence on its equity alliance portfolio. This study calculates the relative alternatives as the number of equity alliance partners with the same three-digit US SIC 
code that a firm has in the announcement year. Higher values indicate that the focal firm maintains many alternative ties to firms other than that partner, resulting in a strong bargaining position. We also control for the potential moderating effect of bargaining power. Smaller firms may have disadvantages in negotiations that are necessary to translate bargaining power into improved conditions in the equity alliance relationship (Ariño et al. 2008; Sarkar et al. 2001; Gomes-Casseres 1997). Larger firms can take more risk in periods of low perceived financial performance due to a greater availability of slack resources (Audia \& Greve 2006; Greve 2011). Furthermore, in an alliance, the financial performance effects of resources may pose a bargaining power component. To isolate the bargaining power component from the IC, OC, and PFRs, the interaction terms are included in the regression analysis.

\subsubsection{Available slack}

The literature has identified slack as an important variable when measuring a firm's financial performance. Firms with more slack may be better equipped to meet their immediate operational financial needs; slack functions as a cushion for environmental shocks and can be used to exploit new opportunities (Lin et al. 2009; Daniel et al. 2004). Consistent with Daniel et al. (2004), we measured available slack as the current ratio (current assets divided by current liabilities).

\subsubsection{Multi-partner partnership}

This study controls for the difference between dyadic and multi-partner partnerships via the dummy variable multipartner partnership. This variable has a value of 1 , as the alliance consists of more than two partners; a value of 0 would be applied if the firm had only one alliance partner. This variable is included in the analysis because of the following differences between a multi-partner partnership and dyadic partnership: Firstly, a multi-partner partnership has an increased level of risk (García-Canal et al. 2003). Secondly, in a multi-partner partnership, the formal control instead of relational investments becomes a more relevant influence on financial performance (García-Canal et al. 2003). Lastly, in a multi-partner partnership, the communication (i.e. lines of communication), coordination, and monitoring activities are more complex and costly than in a dyadic partnership (García-Canal et al. 2003; Park \& Russo 1996).

\subsubsection{Focal firm number of partners}


The variable focal firm number of partners measures the annual alliance network additions (both listed and nonlisted alliance partners). This variable controls for a focal firm having multiple SEA deals in one year.

\subsubsection{Related diversification}

This study measured related diversification with the related dummy variable, which has a value of 1 if the primary US-SIC code of both partners is equal; otherwise it has a value of 0 . The primary US-SIC code of both partners was measured on a three-digit level. This variable controls for industry specific resources (Das \& Teng 2000). The industry specificity is tested via interactions between the variables of related alliance, partner firm OC, and partner firm PFRs.

\subsubsection{International alliance}

The variable international alliance has a value of 1 if the headquarters country location of the partner firm is different from the headquarters country location of the focal firm; otherwise it has a value of 0 .

\subsubsection{Industry diversification (Hirschman Index)}

This study used the sales concentration measure as a measure of diversification. A higher concentration measure indicates a lower diversification. Firms that are more focused on a limited number of industries may focus their resources on that limited number. This study used the original Hirschman Index formula (Szpiro 1987), which is derived from the Euclidean norm. This allows one to measure distances between concentrations, both for crossindustry analyses and for time series studies (Szpiro 1987, p. 302). To measure the firm level industry concentration, this study adopted the approach of Ehie and Olibe (2010, p. 130). The industry diversification measure has the value 1 if the firm is selling its products in 1 SIC industry sector, and if the number of industries increases the value of the industry diversification variable will decrease. The industry diversification measure will always be a number between 0 and 1 , where zero means a very large diversification and one means no diversification.

\subsubsection{Focal firm organizational capital}


This study included the focal firm OC as a control variable to separate the effects of the OC of the focal firm from the OC of the partner firm. The focal firm OC and PFR may have a risk on multicollinearity due to the size effect; therefore, the focal firm OC was normalized by the division by focal firm sales.

\subsubsection{Focal firm production factor resources}

This study included the focal firm's PFRs as a control variable to separate the effects of the PFRs of the focal firm from the PFRs of the partner firm. Both PFRs may have a risk on multicollinearity due to the size effect; therefore, both PFRs, the financial and labor PFRs, were normalized by the division through focal firm sales.

\section{Results}

Descriptive statistics, including the mean and standard deviations, can be found in Table 1. The dataset consists of repeated measurements of the same variables at different points in time. We applied a fixed-effects linear mixed model with maximum likelihood estimation, thereby incorporating appropriate controls for time-invariant variables.

To account for the repeated measurements, this study used an autoregressive covariance structure of the first order. The autoregressive term allows for incorporating the potential autocorrelation due to repeated time measures and is appropriate when there is equal spacing between the time points (Singer \& Willett 2003). We used the Toeplitz covariance structure because it is a more flexible autoregressive structure than AR1 (Hedeker \& Gibbons 2006; Lu \& Mehrotra 2010; Singer \& Willett 2003).

Missing values were treated with list-wise deletion, which resulted in a slight variation in the number of observations between the different models. The analyses were performed in a hierarchical way, first introducing the firm's fixed effects and the contextual control variables, and then adding the independent and moderating firm's specific variables. To ensure the robustness and stability of the empirical model, we added stepwise firm-specific control variables to the basic model. Conclusions were drawn based on the full model (Model 7). We examined the improvement of fit by comparing each model to the baseline model.

Insert Table 1 
We examined multicollinearity by inspecting the iteration history; a high number of iterations are a sign of non-convergence problems that can be attributed to multicollinearity (Shieh \& Fouladi 2003; Neumann 2002). The linear mixed model converged in less than 30 iterations, suggesting that there were no significant problems with multicollinearity. In addition, we used an OLS regression analysis with the same model to inspect the VIF scores and the condition indexes; all VIF scores (Model 7) were below 5 except partner labor PFR (6.43) and the partner OC (5.17), and the highest condition index was 13.99 (Model 7) which is below the threshold of 15 indicating that there is no problem with multicollinearity (Belsley et al. 1980; Belsley 1991). The results reported in this section are conditional invariant regression effects (Hayes et al. 2012).

Conclusions were made based on Model 3 for hypotheses 1a, 2a, and 2b, and the conclusions were based on Model 7 (the full model) for hypotheses $1 \mathrm{~b}, 2 \mathrm{c}$, and $2 \mathrm{~d}$. By comparing the variance of the different models, we found that adding the set of variables significantly improves the goodness of fit for all estimated models. All subsequent models add a substantial explanatory value when compared to the baseline Model 1 .

\section{Insert Tables 2 about here}

In the baseline model (Model 1), the control variables are regressed. The results show that the focal firm available slack is positively significant $(\beta=0.02, \mathrm{p}<0.05)$. This indicates that, in general, firms with more available slack can generate more rents from equity alliances. This confirms the results of Bromiley (1991). The focal firm industry diversification (Hirschman Index) is negatively significant $(\beta=-0.03, p<0.001)$. This indicates that if the focal firm is focusing its sales on a single industry, it may become less profitable. The focal firm OC has a significant negative effect on financial performance $(\beta=-0.09, \mathrm{p}<0.001)$. This negative result of the focal firm OC on the focal firm's return on assets is a result of the prudence (conservatism) principle in accounting; this can be considered as a cost/benefit mismatch (Amir \& Lev 1996). The focal firm financial PFR has a positive significant effect on financial performance $(\beta=0.06, \mathrm{p}<0.001)$. This implies that the focal firm's financial PFR gives the focal firm the flexibility to respond to changes in the marketplace (Mishina et al. 2004). The focal firm labor PFR has a negative significant effect on financial performance $(\beta=-0.02, p<0.05)$. The effect of the focal firms' total number of partners is positive and significant $(\beta=0.02, \mathrm{p}<0.05)$. This implies that a larger network of SEA partners 
improves the focal firms' financial performance. The effect of the multi-partner partnerships, related diversification, and international alliances, are not significant.

In Model 3, the independent variables and firm-specific control variables were added to the regression analysis. The results show that the partner firm's OC has a highly significant negative effect on financial performance $(\beta=-0.05, \mathrm{p}<0.001)$. The structured coefficient (Courville \& Thompson 2001; Nathans et al. 2012; Thompson 2006) confirms this finding $\left(\mathrm{r}_{\mathrm{s}}=-0.15\right)$, which supports Hypothesis 1a. The partner's financial PFR $(\beta=$ $0.03, \mathrm{p}<0.001)$ and the partner's labor PFR $(\beta=0.06, \mathrm{p}<0.001)$ have a substantial and positive significant effect on financial performance. The structured coefficient shows a similar importance for the partners' financial PFR $\left(\mathrm{r}_{\mathrm{s}}=\right.$ $0.04)$ and labor PFR $\left(r_{s}=0.22\right)$ variables, which supports Hypothesis $2 a$ and $2 b$, respectively. The value of the partners' financial PFR structured coefficient is considerably lower than the partners' labor PFRs. This is not the same as the difference in the beta values of these variables, which suggests that the partners' financial PFRs are considerably less important than the partners' labor PFRs. In line with expectations, the control variable of relative focal firm profitability is positive and significant $(\beta=0.12, \mathrm{p}<0.001)$, and the focal firms' relative number of alternatives is not significant. Focal firm relative size has a positive significant direct effect on the focal firm's financial performance $(\beta=0.03, \mathrm{p}<0.001)$. The structured coefficient confirms this finding $\left(\mathrm{r}_{\mathrm{s}}=0.09\right)$. The positive significant effect of relative size on financial performance (ROA) implies that if the relative size of the focal firm in comparison to its partner firm increases, which is conditional on the influence of the relative focal firm profitability (Hayes et al. 2012), the focal firm may benefit from a large resource commitment or the economies of scale. The financial performance effects of the partner OC and PFR are illustrated in Figure 1, which shows that partner OC has on average a negative effect on the focal firm's financial performance. Figure 1 shows that when the partner firm OC increases, the focal firm's financial performance decreases considerably. This reinforces our argument that organizational routines are in general not transferrable across firm boundaries. In contrast, Figure 1 depicts the opposite general pattern for PFRs: both financial and labor PFRs have a positive effect on the focal firm's financial performance, indicating that more codified resources are easily transferrable across firm boundaries.

In Model 4, we control for interactions with the industry-relatedness and if the alliance concerns an international partner to account for industry and culture-related influences. In Model 5, we control for structural dependence-related influences. In Model 6, we control for the relative profitability of the focal firm. In Model 7 (full model), the control interactions and the interactions between relative size, OC, and PFRs are included in the 
regression analysis. In Model 7, the direct effects of the partner OC and financial PFR are not significant. This implies that the direct effects are contingent on the interactions with industry-relatedness, international alliances, bargaining power, and relative size. The direct effect of the partner firm labor PFR stays positive and significant ( $\beta$ $=0.03, \mathrm{p}<0.001$ ), which implies that the financial performance effects of partner firm labor PFRs are not completely explained by the interactions. In the model, we controlled for the effect of the interaction between industry-relatedness and the partner OC and PFRs, and for the interaction between the bargaining power and partner OC and PFRs.

The results show that the interaction between partner firm OC and industry-relatedness is negative and significant $(\beta=-0.05, \mathrm{p}<0.001)$; this implies that, conditional on the influence of the partner firm OC and industryrelatedness (Hayes et al. 2012), allying with a partner firm in the same industry with a high amount of OC has a negative effect on the focal firm's financial performance. The interaction between industry-relatedness and the partner firm financial PFR $(\beta=0.06, p<0.001)$ is positive and significant, implying that allying with a partner firm in the same industry has a positive effect on financial performance. The interaction between industry-relatedness and partner firm labor PFR is not significant. The interactions between international alliance and partner firm OC and PFRs are not significant. The interaction between relative focal firm profitability and relative size is negatively significant $(\beta=-0.05, \mathrm{p}<0.001)$. This indicates that if the focal firm contributes a relatively large amount of resources to the alliance and if it has relative high bargaining power, this can have a negative impact on financial performance.

We controlled for the structural dependence of the focal firm on the partner firm via the focal firm's relative alternatives interactions. The interaction between partner firm OC and relative alternatives is positive and significant $(\beta=0.01, p<0.05)$, and the interaction between partner firm financial PFR and relative alternatives is negative and significant $(\beta=-0.01, \mathrm{p}<0.05)$. The interaction between partner firm labor PFR and relative alternatives is not significant. These results indicate that, although their effect is very small, the structural dependence on partner firm resources can improve the financial performance in case of OCs but decrease financial performance in case of financial PFRs.

The interaction between relative focal firm profitability and the partner firm's OC has a negative and significant effect on financial performance $(\beta=-0.02, \mathrm{p}<0.001)$. By controlling for the moderating effect of relative focal firm profitability on the partner firm OC, the main effect of the partner firm OC (Hypothesis 1a) is no longer 
significant. This shows that the moderating effects of industry-relatedness, international alliances, and relative focal firm profitability explain more than the direct effect of partner firm OC on financial performance.

The interaction between relative focal firm profitability and the partner firm's financial PFR has a positive significant effect on the focal firm financial performance $(\beta=0.03, p<0.001)$. The interaction between the focal firm's relative profitability and the partner firm's labor PFR has a positive significant effect on the focal firm's financial performance $(\beta=0.02, \mathrm{p}<0.001)$. This indicates that bargaining power can be applied more effectively on the partner firm's PFR than on the partner firm's OC.

The interaction between the relative focal firm size and a partner firm's OC has a significant positive effect on financial performance $(\beta=0.02, \mathrm{p}<0.001)$. The structured coefficient (Courville \& Thompson 2001; Nathans et al. 2012; Thompson 2006) confirms this finding $\left(\mathrm{r}_{\mathrm{s}}=-0.04\right)$, which supports Hypothesis $1 \mathrm{~b}$. Thus, a relatively larger firm can benefit from its alliance partner's OC (see Figure 2). In Figure 2, the interaction effects between partner firm OC and focal firm relative size are illustrated. Figure 2 shows that when a partner has a low amount of OC, the focal firm is not significantly affected regardless of the relative size of the alliance partners. However, if the partner firm has a high amount of OC and the focal firm is larger than the partner firm, it can benefit from the partner's OC, whereas if the focal firm is smaller than the partner firm, it reduces its financial performance significantly.

The interactions between focal firm relative size and the partner firm's financial PFR $(\beta=-0.03, p<0.001)$ and labor PFR $(\beta=-0.02, \mathrm{p}<0.01)$ both have a negative significant effect on the focal firm's financial performance; the structured coefficient of the partner firm's financial PFR $\left(r_{s}=-0.07\right)$ and labor PFR $\left(r_{s}=-0.06\right)$ confirms this finding, which supports Hypothesis 2c and 2d, respectively. In Figures 3 and 4, the interaction effects of the partner PFRs and the relative size are illustrated. In Figures 3 and 4, it becomes clear that when the partner has either a low financial or labor PFR, the relative size is the cause of considerable financial performance differences. If the focal firm is relatively larger than the partner firm, it performs significantly better than when the focal firm is relatively smaller than the partner firm. When the partner firm has either high financial or high labor PFRs, the financial performance difference becomes relatively small. Although, the labor PFRs have a benefit for both larger and smaller firms, smaller firms see a much larger financial performance increase with a labor PFR partner than a larger firm. From the perspective of a relatively small firm, partner firm labor resources are more beneficial than partner firm financial resources. 
By comparing the goodness of fit between the models (Models 1 to 7), the results in Table 2 show that the independent variables of partner firm OC and the partner firm's financial and labor PFRs significantly improve the goodness of fit, which suggests that these variables significantly contribute to the explanation of a firm's financial performance. All subsequent models add substantial and significant explanatory power when compared to the baseline model (Model 1).

Insert Table 2 about here

\section{Discussion}

This study explored the role of partner resources in SEA networks for smaller and larger firms. We argued that the degree to which the partner resources are context-free may have a substantial impact on their transferability to, and integration into, the focal firm. In the economics and management literature, it is often assumed that in alliances with larger firms, smaller firms face more challenges in integrating knowledge than their larger counterparts (van de Vrande et al. 2009) and are more sensitive to hold-up in alliances (Ariño et al. 2008) due to higher specific investments. This puts them at a disadvantage in the learning race. Our results also show that smaller firms in SEA networks are less able to integrate the OC of larger firms; however, we also found that smaller firms benefit more from PFRs compared to larger partner firms. Our results, therefore, show a much more complex picture for smaller firms in SEA networks where they face threats but also substantial opportunities in alliances with larger firms.

\subsection{Contribution to theory}

The results of this study support the idea that there is a need for a better definition and classification of "firm resources", as suggested by critics of the resourced-based view (see Kraaijenbrink et al. (2010)). Particularly, these critics argued that the resource-based view is tautological in nature. A tautology is an analytic statement presented as a synthetic statement and therefore is not falsifiable (Bacharach 1989); many scientific theories such as evolutionary theory make use of tautologies (Donaldson 2001). The way to transform a tautological statement into a falsifiable scientific statement is to develop more specific content to the theoretical statement. In our paper, we 
developed such specific content by distinguishing between different attributes of partner resources and their impact on firm financial performance of smaller firms (Lyles \& Salk 2007; Thuc Anh et al. 2006). By developing specific content, our framework addresses the criticism that the resource-based view is tautological. We theorized a relative size dependent negative effect of partner OC and a relative size dependent positive effect for a partner's PFRs on focal firm financial performance, and we found strong support for our theory.

The resource-based view regards resources as having an extrinsic but constant value, and the focus lies on the integration (Harrison et al. 2001) and the transfer (Speckbacher et al. 2015) of these resources. The contingent resource-based view expands this line of thought by arguing that a resource needs to be aligned with the context in which it is deployed (Brush \& Artz 1999). Gander et al. (2007) have shown that the value of resources is tied to the context in which they are used, which is in line with the contingent resource-based view (Brush \& Artz 1999; Priem \& Butler 2001; Verwaal et al. 2009). The resource-based view considers that alliances management, if properly done, is a form of resource picking (Marino et al. 2008), in which orchestration of resources (Sirmon et al. 2011) is the main concern. However, the present study demonstrates that the value of organization-specific (embedded) resources depends on the relative size in which they are deployed. In contrast, resources that are more codified and explicit, and therefore more context-free, can be managed well in an alliance and contribute positively to smaller firms' financial performances.

\subsection{Managerial implications}

The findings of this study have several implications for managers when designing and managing access and control of resources. First, managers should recognize that partner resources can be both a threat and an opportunity in SEAs, depending on the relative size of the firm. PFRs may generate superior financial performance in an equity alliance setting; this particularly applies to the smaller firm in the SEA. Of course, in this context, entrepreneurs or small business managers should secure their knowledge and ensure that it is sufficiently codified and legally protected (i.e., contracts, patents, and licensing), or protected their knowledge in informal ways such as trade secrets and timing defense options (Katila et al. 2008). In contrast, a partner's OC has a persistent negative effect on the focal firm's financial performance, particularly for the smaller firm. Smaller firms and the organizational and structural properties that come with smaller size may hamper the capacity to absorb the partner's OC. In an SEA setting, OC can be detrimental to the smaller focal firm's financial performance; only larger firms with their 
specialized knowledge integration systems may partially compensate for this negative financial performance effect. Overall, the results suggest that managers can optimize resource complementarities in equity alliance relationships, depending on the attributes of the resource endowments of the partner firm.

\subsection{Limitations}

Although this study contributes to the understanding of the role of resource attributes in equity alliance strategies, it does have limitations that may be addressed by future research. Firstly, there may be more resource classifications that can explain the rent generation of firms. Transaction attributes, the superior expectations of future resource value, and resource scarcity are not included in this study. Future studies could include these variables in their frameworks.

Secondly, the equity alliance relationships included in the databases used for this study may not include all relevant equity alliance relationships. Specifically, firms may also participate in informal equity alliance relationships that are not included in the database. Future research could include more informal equity alliance relationships in their research designs. Despite these limitations, this study demonstrates that contextual factors can help to explain resource strategies and thus help managers to design and manage resource access and control strategies more effectively.

Thirdly, in this study we used the three-digit US SIC code as proxy for the industry classification. McGahan and Porter (1997) have argued that the use of the SIC system for industry classification could diminish the measurement estimates because the SIC industry classifications are overly broad. Thus, a more narrowly specified industry classification could strengthen the measurement estimates for variables such as the focal firm relative alternatives and related industry. Researchers could explore if a more narrowly defined industry classification influences the results of this study.

In addition to the variables included in this study, one could explore the scope of resources in strategic equity alliance partnerships in terms of industry activities or geography. Firms may be better able to combine equity alliance resources in a diverse network of equity alliances across different countries and industries. In a world where information advantages are more difficult to find and powerful bargaining positions may attract the attention of antitrust authorities, the capability to create value through the superior combination of complementary resources may become increasingly important for sustainable competitive strategies. 
Researchers in the organizational studies field can expand this model by investigating how smaller firms interact with equity alliance networks and how their distinct organizational nature can benefit or hinder either party or their interaction. For example, there is only sparse research on how organizational, resource-based partner organizations influence the financial performance of smaller focal firms. Given the important role of interaction between smaller and larger firms in fostering entrepreneurship and innovation, this line of research needs further development to further explore the potential of smaller firms in entrepreneurial networks.

Acknowledgements

The authors would like to thank two anonymous reviewers for their constructive and insightful comments. In addition, the authors would like to thank the external examiner Professor John Child and Professor Edwin Nijssen for their helpful comments during the development phase of this manuscript.

\section{References}

Aaltonen, A., \& Lanzara, G. F. (2015). Building governance capability in online social production: Insights from wikipedia. Organization Studies, 36(12), 1649-1673. doi: $10.1177 / 0170840615584459$

Acs, Z. J., Morck, R. K., Shaver, J. M. et al. (1997). The internationalization of small and medium-sized enterprises: A policy perspective. Small Business Economics, 9(1), 7-20. doi: 10.1023/A:1007991428526

Ahuja, G. (2000). Collaboration networks, structural holes, and innovation: A longitudinal study. Administrative Science Quarterly, 45(3), 425-455. doi: 10.2307/2667105

Al-Laham, A., Amburgey, T. L., \& Baden-Fuller, C. (2010). Who is my partner and how do we dance? Technological collaboration and patenting speed in us biotechnology. British Journal of Management, 21(3), 789-807. doi: 10.1111/j.1467-8551.2010.00689.x

Alvarez, S., A. , \& Barney, J. B. (2001). How entrepreneurial firms can benefit from alliances with large partners. The Academy of Management Executive (1993-2005), 15(1), 139148. doi: $10.5465 /$ ame. 2001.4251563

Alvarez, S. A., \& Busenitz, L. W. (2001). The entrepreneurship of resource-based theory. Journal of Management, 27(6), 755-775. doi: 10.1177/014920630102700609

Amir, E., \& Lev, B. (1996). Value-relevance of nonfinancial information: The wireless communications industry. Journal of Accounting and Economics, 22(1-3), 3-30. doi: 10.1016/S0165-4101(96)00430-2

Amit, R., \& Schoemaker, P. J. H. (1993). Strategic assets and organizational rent. Strategic Management Journal, 14(1), 33-46. doi: 10.2307/2486548

Aoyama, Y., \& Izushi, H. (2003). Hardware gimmick or cultural innovation? Technological, cultural, and social foundations of the japanese video game industry. Research Policy, 32(3), 423-444. doi: 10.1016/S0048-7333(02)00016-1 
Argyres, N. S., Felin, T., Foss, N. et al. (2012). Organizational economics of capability and heterogeneity. Organization Science, 23(5), 1213-1226. doi: 10.1287/orsc. 1120.0746

Ariño, A., Ragozzino, R., \& Reuer, J. J. (2008). Alliance dynamics for entrepreneurial firms. Journal of Management Studies, 45(1), 147-168. doi: 10.1111/j.1467-6486.2007.00745.x

Audia, P. G., \& Greve, H. R. (2006). Less likely to fail: Low performance, firm size, and factory expansion in the shipbuilding industry. Management Science, 52(1), 83-94. doi: 10.1287/mnsc. 1050.0446

Bacharach, S. B. (1989). Organizational theories: Some criteria for evaluation. Academy of Management Review, 14(4), 496-515. doi: 10.5465/amr.1989.4308374

Bacharach, S. B., \& Lawler, E. J. (1981). Bargaining, power, tactics, and outcomes. San Francisco: Jossey-Bass.

Barney, J. B. (1986). Strategic factor markets: Expectations, luck, and business strategy. Management Science, 32(10), 1231-1241. doi: 10.1287/mnsc.32.10.1231

Barringer, B. R., \& Harrison, J. S. (2000). Walking a tightrope: Creating value through interorganizational relationships. Journal of Management, 26(3), 367-403. doi: $10.1177 / 014920630002600302$

Belsley, D. A. (1991). A guide to using the collinearity diagnostics. [journal article]. Computer Science in Economics and Management, 4(1), 33-50. doi: 10.1007/bf00426854

Belsley, D. A., Kuh, E., \& Welsch, R. E. (1980). Regression diagnostics: Identifying influential data and sources of collinearity. New York: Wiley.

Bercovitz, J., \& Mitchell, W. (2007). When is more better? The impact of business scale and scope on long-term business survival, while controlling for profitability. Strategic Management Journal, 28(1), 61-79. doi: 10.1002/smj.568

Berman, S. L., Down, J., \& Hill, C. W. L. (2002). Tacit knowledge as a source of competitive advantage in the national basketball association. The Academy of Management Journal, 45(1), 13-31. doi: 10.2307/3069282

Borgatti, S. P., \& Halgin, D. S. (2011). On network theory. Organization Science, 22(5), 11681181. doi: 10.1287/orsc. 1100.0641

Boyd, B. K., Dess, G. G., \& Abdul, M. a. R. (1993). Divergence between archival and perceptual measures of the environment: Causes and consequences. The Academy of Management Review, 18(2), 204-226. doi: 10.5465/amr.1993.3997514

Bromiley, P. (1991). Testing a causal model of corporate risk taking and performance. The Academy of Management Journal, 34(1), 37-59. doi: 10.2307/256301

Brush, T. H., \& Artz, K. W. (1999). Toward a contingent resource-based theory: The impact of information asymmetry on the value of capabilities in veterinary medicine. Strategic Management Journal, 20(3), 223-250. doi: 10.1002/(sici)10970266(199903)20:3<223::aid-smj14>3.0.co;2-m

Burgers, W. P., Hill, C. W. L., \& Kim, W. C. (1993). A theory of global strategic alliances: The case of the global auto industry. Strategic Management Journal, 14(6), 419-432. doi: $10.2307 / 2486753$

Burt, R. S. (1992). Structural holes: The social structure of competition. Cambridge, Massachusetts Harvard University Press.

Campbell-Kelly, M. (2004). From airline reservations to sonic the hedgehog: A history of the software industry. Cambridge, Massachusetts: MIT Press.

Campbell, A., Goold, M., \& Alexander, M. (1995). Corporate strategy: The quest for parenting advantage. Harvard Business Review, 7(3), 120-132. 
Carmona-Lavado, A., Cuevas-Rodríguez, G., \& Cabello-Medina, C. (2010). Social and organizational capital: Building the context for innovation. Industrial Marketing Management, 39(4), 681-690. doi: 10.1016/j.indmarman.2009.09.003

Caves, R. E. (2000). Creative industries: Contracts between art and commerce. Cambridge, Massachusetts Harvard University Press.

Cheng, S. (2004). R\&d expenditures and ceo compensation. The Accounting Review, 79(2), 305328. doi: $10.2307 / 3203246$

Cohen, J., Cohen, P., West, S. G. et al. (2003). Applied multiple regression/correlation analysis, for the behavioral science (3 ed.). Mahwah, New Jersey: Lawrence Erlbaum Associates Inc.

Courville, T., \& Thompson, B. (2001). Use of structure coefficients in published multiple regression articles: B is not enough. Educational and Psychological Measurement, 61(2), 229-248. doi: 10.1177/0013164401612006

Daniel, F., Lohrke, F. T., Fornaciari, C. J. et al. (2004). Slack resources and firm performance: A meta-analysis. Journal of Business Research, 57(6), 565-574. doi: 10.1016/S01482963(02)00439-3

Das, S., Sen, P. K., \& Sengupta, S. (1998). Impact of strategic alliances on firm valuation. The Academy of Management Journal, 41(1), 27-41. doi: 10.2307/256895

Das, T. K., \& Teng, B.-S. (2000). A resource-based theory of strategic alliances. Journal of Management, 26(1), 31-61. doi: 10.1177/014920630002600105

Dierickx, I., \& Cool, K. (1989). Asset stock accumulation and sustainability of competitive advantage. Management Science, 35(12), 1504-1511. doi: 10.1287/mnsc.35.12.1504

Donaldson, L. (2001). The contingency theory of organizations. Thousand Oaks, California: SAGE Publications.

Dosi, G., Faillo, M., \& Marengo, L. (2008). Organizational capabilities, patterns of knowledge accumulation and governance structures in business firms: An introduction. Organization Studies, 29(8-9), 1165-1185. doi: 10.1177/0170840608094775

Dougherty, D. (1992). Interpretive barriers to successful product innovation in large firms. Organization Science, 3(2), 179-202. doi: 10.2307/2635258

Dyer, J. H., \& Nobeoka, K. (2000). Creating and managing a high-performance knowledgesharing network: The toyota case. Strategic Management Journal, 21(3), 345-367. doi: $10.2307 / 3094191$

Ehie, I. C., \& Olibe, K. (2010). The effect of r\&d investment on firm value: An examination of us manufacturing and service industries. International Journal of Production Economics, 128(1), 127-135. doi: 10.1016/j.ijpe.2010.06.005

Eisenhardt, K. M., \& Martin, J. A. (2000). Dynamic capabilities: What are they? Strategic Management Journal, 21(10-11), 1105-1121. doi: 10.1002/10970266(200010/11)21:10/11<1105::aid-smj133>3.0.co;2-e

Eisenhardt, K. M., \& Schoonhoven, C. B. (1996). Resource-based view of strategic alliance formation: Strategic and social effects in entrepreneurial firms. Organization Science, 7(2), 136-150. doi: 10.1287/orsc.7.2.136

Ellis, P. D. (2011). Social ties and international entrepreneurship: Opportunities and constraints affecting firm internationalization. Journal of International Business Studies, 42(1), 99127. doi: $10.1057 /$ jibs.2010.20

Fiol, C. M., \& Lyles, M. A. (1985). Organizational learning. The Academy of Management Review, 10(4), 803-813. doi: 10.5465/amr.1985.4279103 
Fisher, L. M. (1996). How strategic alliances work in biotech. Strategy and Business, Winter $1996(2), 1-7$.

Gander, J., Haberberg, A., \& Rieple, A. (2007). A paradox of alliance management: Resource contamination in the recorded music industry. Journal of Organizational Behavior, 28(5), 607-624. doi: 10.1002/job.463

Gander, J., \& Rieple, A. (2002). Inter-organisational relationships in the worldwide popular recorded music industry. Creativity and Innovation Management, 11(4), 248-254. doi: $10.1111 / 1467-8691.00256$

García-Canal, E., Valdés-Llaneza, A., \& Ariño, A. (2003). Effectiveness of dyadic and multiparty joint ventures. Organization Studies, 24(5), 743-770. doi: 10.1177/0170840603024005004

Goerzen, A., \& Beamish, P. W. (2005). The effect of alliance network diversity on multinational enterprise performance. Strategic Management Journal, 26(4), 333-354. doi: 10.1002/smj.447

Gomes-Casseres, B. (1997). Alliance strategies of small firms. Small Business Economics, 9(1), 33-44. doi: 10.1023/a:1007947629435

Granovetter, M. S. (1973). The strength of weak ties. American Journal of Sociology, 78(6), 1360-1380.

Granovetter, M. S. (1983). The strength of weak ties: A network theory revisited. Sociological Theory, 1, 201-233. doi: 10.2307/202051

Grant, R. M. (1996a). Prospering in dynamically-competitive environments: Organizational capability as knowledge integration. Organization Science, 7(4), 375-387. doi: $10.2307 / 2635098$

Grant, R. M. (1996b). Toward a knowledge-based theory of the firm. Strategic Management Journal, 17(S2), 109-122. doi: 10.2307/2486994

Greenwood, R., Li, S. X., Prakash, R. et al. (2005). Reputation, diversification, and organizational explanations of performance in professional service firms. Organization Science, 16(6), 661-673. doi: 10.2307/25146002

Greve, H. R. (2011). Positional rigidity: Low performance and resource acquisition in large and small firms. Strategic Management Journal, 32(1), 103-114. doi: 10.1002/smj.875

Griffin, A., \& Hauser, J. R. (1996). Integrating r\&d and marketing: A review and analysis of the literature. Journal of Product Innovation Management, 13(3), 191-215. doi: 10.1111/1540-5885.1330191

Grossman, S. J., \& Hart, O. D. (1986). The costs and benefits of ownership: A theory of vertical and lateral integration. Journal of Political Economy, 94(4), 691-719. doi: $10.2307 / 1833199$

Gulati, R., \& Singh, H. (1998). The architecture of cooperation: Managing coordination costs and appropriation concerns in strategic alliances. Administrative Science Quarterly, 43(4), 781-814. doi: 10.2307/2393616

Hannan, M. T., \& Freeman, J. (1984). Structural inertia and organizational change. American Sociological Review, 49(2), 149-164. doi: 10.2307/2095567

Hansen, M. T. (1999). The search-transfer problem: The role of weak ties in sharing knowledge across organization subunits. Administrative Science Quarterly, 44(1), 82-111. doi: $10.2307 / 2667032$

Hargadon, A. (1998). Firms as knowledge brokers. California Management Review, 40(3), 209227. 
Harrison, J. S., Hitt, M. A., Hoskisson, R. E. et al. (2001). Resource complementarity in business combinations: Extending the logic to organizational alliances. Journal of Management, 27(6), 679-690. doi: 10.1177/014920630102700605

Hayes, A. F., Glynn, C. J., \& Huge, M. E. (2012). Cautions regarding the interpretation of regression coefficients and hypothesis tests in linear models with interactions. Communication Methods and Measures, 6(1), 1-11. doi: 10.1080/19312458.2012.651415

Hedeker, D., \& Gibbons, R. D. (2006). Longitudinal data analysis. Hoboken, New Jersey: John Wiley \& Sons.

Hennart, J.-F., \& Zeng, M. (2005). Structural determinants of joint venture performance. European Management Review, 2(2), 105-115. doi: 10.1057/palgrave.emr.1500034

Hertz, S., \& Alfredsson, M. (2003). Strategic development of third party logistics providers. Industrial Marketing Management, 32(2), 139-149. doi: 10.1016/S0019-8501(02)002286

Hitt, M. A., \& Ireland, R. D. (1986). Relationships among corporate level distinctive competencies, diversification strategy, corporate structure and performance. Journal of Management Studies, 23(4), 401-416. doi: 10.1111/j.1467-6486.1986.tb00425.x

Hsu, D. H. (2007). Experienced entrepreneurial founders, organizational capital, and venture capital funding. Research Policy, 36(5), 722-741. doi: 10.1016/j.respol.2007.02.022

Inkpen, A. (1998). Learning, knowledge acquisition, and strategic alliances. European Management Journal, 16(2), 223-229. doi: 10.1016/S0263-2373(97)00090-X

Ireland, R. D., Hitt, M. A., \& Vaidyanath, D. (2002). Alliance management as a source of competitive advantage. Journal of Management, 28(3), 413-446. doi: 10.1016/s01492063(02)00134-4

Jarillo, J. C. (1989). Entrepreneurship and growth: The strategic use of external resources. Journal of Business Venturing, 4(2), 133-147. doi: 10.1016/0883-9026(89)90027-X

Jensen, M. C. (1986). Agency costs of free cash flow, corporate finance, and takeovers. The American Economic Review, 76(2), 323-329. doi: 10.2307/1818789

Kalaignanam, K., Shankar, V., \& Varadarajan, R. (2007). Asymmetric new product development alliances: Win-win or win-lose partnerships? Management Science, 53(3), 357-374. doi: $10.2307 / 20110704$

Kale, P., Dyer, J. H., \& Singh, H. (2002). Alliance capability, stock market response, and longterm alliance success: The role of the alliance function. Strategic Management Journal, 23(8), 747-767. doi: 10.1002/smj.248

Katila, R., \& Ahuja, G. (2002). Something old, something new: A longitudinal study of search behavior and new product introduction. The Academy of Management Journal, 45(6), 1183-1194. doi: 10.2307/3069433

Katila, R., Rosenberger, J. D., \& Eisenhardt, K. M. (2008). Swimming with sharks: Technology ventures, defense mechanisms and corporate relationships. Administrative Science Quarterly, 53(2), 295-332. doi: 10.2189/asqu.53.2.295

Khoury, T. A., \& Pleggenkuhle-Miles, E. G. (2011). Shared inventions and the evolution of capabilities: Examining the biotechnology industry. Research Policy, 40(7), 943-956. doi: 10.1016/j.respol.2011.05.007

Killing, J. P. (1983). Strategies for joint venture success. New York: Praeger.

Kim, H., Hoskisson, R. E., \& Wan, W. P. (2004). Power dependence, diversification strategy, and performance in keiretsu member firms. Strategic Management Journal, 25(7), 613636. doi: $10.1002 / \mathrm{smj} .395$ 
King, A. W. (2007). Disentangling interfirm and intrafirm causal ambiguity: A conceptual model of causal ambiguity and sustainable competitive advantage. The Academy of Management Review, 32(1), 156-178. doi: 10.5465/amr.2007.23464002

Koh, J., \& Venkatraman, N. (1991). Joint venture formations and stock market reactions: An assessment in the information technology sector. The Academy of Management Journal, 34(4), 869-892. doi: 10.2307/256393

Kraaijenbrink, J., Spender, J.-C., \& Groen, A. J. (2010). The resource-based view: A review and assessment of its critiques. Journal of Management, 36(1), 349-372. doi: $10.1177 / 0149206309350775$

Laitner, J. (2000). Structural change and economic growth. The Review of Economic Studies, 67(3), 545-561. doi: 10.1111/1467-937x.00143

Lane, H. W., \& Beamish, P. W. (1990). Cross-cultural cooperative behavior in joint ventures in ldcs. Management International Review, 30(special issue), 87-102.

Lane, P. J., \& Lubatkin, M. (1998). Relative absorptive capacity and interorganizational learning. Strategic Management Journal, 19(5), 461-477. doi: 10.1002/(sici)10970266(199805)19:5<461::aid-smj953>3.0.co;2-1

Larson, A. (1991). Partner networks: Leveraging external ties to improve entrepreneurial performance. Journal of Business Venturing, 6(3), 173-188. doi: 10.1016/08839026(91)90008-2

Lechner, C., \& Dowling, M. (2003). Firm networks: External relationships as sources for the growth and competitiveness of entrepreneurial firms. Entrepreneurship \& Regional Development, 15(1), 1-26. doi: 10.1080/08985620210159220

Lev, B., Radhakrishnan, S., \& Zhang, W. (2009). Organization capital. Abacus, 45(3), 275-298. doi: 10.1111/j.1467-6281.2009.00289.x

Lin, W.-T., Cheng, K.-Y., \& Liu, Y. (2009). Organizational slack and firm's internationalization: A longitudinal study of high-technology firms. Journal of World Business, 44(4), 397406. doi: 10.1016/j.jwb.2008.11.003

Lu, K., \& Mehrotra, D. V. (2010). Specification of covariance structure in longitudinal data analysis for randomized clinical trials. Statistics in Medicine, 29(4), 474-488. doi: $10.1002 / \operatorname{sim} .3820$

Lyles, M. A., \& Salk, J. E. (2007). Knowledge acquisition from foreign parents in international joint ventures: An empirical examination in the hungarian context. Journal of International Business Studies, 38(1), 3-18.

Makadok, R. (2001). Toward a synthesis of the resource-based and dynamic-capability views of rent creation. Strategic Management Journal, 22(5), 387-401. doi: 10.1002/smj.158

Makadok, R. (2002). A rational-expectations revision of makadok's resource/capability synthesis. Strategic Management Journal, 23(11), 1051-1057. doi: 10.1002/smj.263

Marino, L. D., Lohrke, F. T., Hill, J. S. et al. (2008). Environmental shocks and sme alliance formation intentions in an emerging economy: Evidence from the asian financial crisis in indonesia. Entrepreneurship Theory and Practice, 32(1), 157-183. doi: 10.1111/j.15406520.2007.00220.x

Marquardt, D. W. (1980). A critique of some ridge regression methods: Comment. Journal of the American Statistical Association, 75(369), 87-91. doi: 10.2307/2287388

Marquardt, D. W., \& Snee, R. D. (1975). Ridge regression in practice. The American Statistician, 29(1), 3-20. doi: 10.2307/2683673 
Mcconnell, J. J., \& Nantell, T. J. (1985). Corporate combinations and common stock returns: The case of joint ventures. The Journal of Finance, 40(2), 519-536. doi: 10.1111/j.15406261.1985.tb04970.x

Mcgahan, A. M., \& Porter, M. E. (1997). How much does industry matter, really? Strategic Management Journal, 18, 15-30. doi: 10.1002/(sici)1097-0266(199707)18:1+<15::aidsmj916>3.0.co;2-1

Mehta, N. (2008). Successful knowledge management implementation in global software companies. Journal of Knowledge Management, 12(2), 42-56. doi: doi:10.1108/13673270810859505

Meier, M. (2011). Knowledge management in strategic alliances: A review of empirical evidence. International Journal of Management Reviews, 13(1), 1-23. doi: 10.1111/j.1468-2370.2010.00287.x

Merchant, H., \& Schendel, D. (2000). How do international joint ventures create shareholder value? Strategic Management Journal, 21(7), 723-737. doi: 10.1002/10970266(200007)21:7<723::aid-smj114>3.0.co;2-h

Miller, D., \& Shamsie, J. (1996). The resource-based view of the firm in two environments: The hollywood film studios from 1936 to 1965. The Academy of Management Journal, 39(3), 519-543. doi: $10.2307 / 256654$

Mincer, J., \& Polachek, S. (1974). Family investments in human capital: Earnings of women. Journal of Political Economy, 82(2), S76-S108.

Mishina, Y., Pollock, T. G., \& Porac, J. F. (2004). Are more resources always better for growth? Resource stickiness in market and product expansion. Strategic Management Journal, 25(12), 1179-1197. doi: 10.1002/smj.424

Moreno, A. M., \& Casillas, J. C. (2008). Entrepreneurial orientation and growth of smes: A causal model. Entrepreneurship Theory and Practice, 32(3), 507-528. doi: 10.1111/j.1540-6520.2008.00238.x

Mudambi, S. M., \& Tallman, S. (2010). Make, buy or ally? Theoretical perspectives on knowledge process outsourcing through alliances. Journal of Management Studies, 47(8), 1434-1456. doi: 10.1111/j.1467-6486.2010.00944.x

Nathans, L. L., Oswald, F. L., \& Nimon, K. (2012). Interpreting multiple linear regression: A guidebook of variable importance. Practical Assessment, Research \& Evaluation, 17(9).

Neffke, F., \& Henning, M. (2013). Skill relatedness and firm diversification. Strategic Management Journal, 34(3), 297-316. doi: 10.1002/smj.2014

Nerkar, A. (2003). Old is gold? The value of temporal exploration in the creation of new knowledge. Management Science, 49(2), 211-229. doi: 10.2307/822515

Neumann, D. E. (2002). An enhanced neural network technique for software risk analysis. Software Engineering, IEEE Transactions on, 28(9), 904-912. doi: $10.1109 /$ tse. 2002.1033229

Newbert, S. L. (2007). Empirical research on the resource-based view of the firm: An assessment and suggestions for future research. Strategic Management Journal, 28(2), 121-146. doi: 10.1002/smj.573

Nidumolu, S. R., \& Subramani, M. R. (2003). The matrix of control: Combining process and structure approaches to managing software development. Journal of Management Information Systems, 20(3), 159-196. doi: 10.1080/07421222.2003.11045774 
Nohria, N., \& Gulati, R. (1997). What is the optimum amount of organizational slack?: A study of the relationship between slack and innovation in multinational firms. European Management Journal, 15(6), 603-611. doi: 10.1016/S0263-2373(97)00044-3

Osborn, R. N., \& Baughn, C. C. (1990). Forms of interorganizational governance for multinational alliances. The Academy of Management Journal, 33(3), 503-519. doi: $10.2307 / 256578$

Oxley, J. E. (1997). Appropriability hazards and governance in strategic alliances: A transaction cost approach. Journal of Law, Economics, \& Organization, 13(2), 387-409. doi: $10.2307 / 765097$

Park, S. H., \& Kim, D. (1997). Market valuation of joint ventures: Joint venture characteristics and wealth gains. Journal of Business Venturing, 12(2), 83-108. doi: 10.1016/S08839026(96)00036-5

Park, S. H., \& Russo, M. V. (1996). When competition eclipses cooperation: An event history analysis of joint venture failure. Management Science, 42(6), 875-890. doi: $10.1287 /$ mnsc. 42.6 .875

Park, S. H., \& Ungson, G. R. (1997). The effect of national culture, organizational complementarity, and economic motivation on joint venture dissolution. The Academy of Management Journal, 40(2), 279-307. doi: 10.2307/256884

Parkhe, A. (1991). Interfirm diversity, organizational learning, and longevity in global strategic alliances. Journal of International Business Studies, 22(4), 579-601. doi: 10.1057/palgrave.jibs.8490315

Peng, M. W., \& Heath, P. S. (1996). The growth of the firm in planned economies in transition: Institutions, organizations, and strategic choice. The Academy of Management Review, 21(2), 492-528. doi: 10.5465/amr.1996.9605060220

Pentland, B. T., \& Feldman, M. S. (2005). Organizational routines as a unit of analysis. Industrial and Corporate Change, 14(5), 793-815. doi: 10.1093/icc/dth070

Pfeffer, J., \& Salancik, G. R. (1978). The external control of organizations: A resource dependence perspective. New York, New York: Harper \& Row.

Pisano, G. P. (1989). Using equity participation to support exchange: Evidence from the biotechnology industry. Journal of Law, Economics, \& Organization, 5(1), 109-126. doi: $10.2307 / 764936$

Porter, M. E. (1985). Competitive advantage: Creating and sustaining superior performance. New York, New York: The Free Press.

Priem, R. L., \& Butler, J. E. (2001). Is the resource-based "view" a useful perspective for strategic management research? The Academy of Management Review, 26(1), 22-40. doi: 10.5465/amr.2001.4011928

Roberts, P. W., \& Dowling, G. R. (2002). Corporate reputation and sustained superior financial performance. Strategic Management Journal, 23(12), 1077-1093. doi: 10.2307/3094296

Rosenberg, N. (1982). Inside the black box: Technology and economics. Cambridge, United Kingdom: Cambridge University Press.

Rosenberg, N. (1994). Exploring the black box: Technology, economics, and history. Cambridge, United Kingdom: Cambridge University Press.

Rosenbusch, N., Brinckmann, J., \& Bausch, A. (2011). Is innovation always beneficial? A metaanalysis of the relationship between innovation and performance in smes. Journal of Business Venturing, 26(4), 441-457. doi: 10.1016/j.jbusvent.2009.12.002 
Rowley, T., Behrens, D., \& Krackhardt, D. (2000). Redundant governance structures: An analysis of structural and relational embeddedness in the steel and semiconductor industries. Strategic Management Journal, 21(3), 369-386.

Rubb, S. (2006). Educational mismatches and earnings: Extensions of occupational mobility theory and evidence of human capital depreciation. Education Economics, 14(2), 135154. doi: 10.1080/09645290600622905

Rus, I., \& Lindvall, M. (2002). Knowledge management in software engineering. IEEE Software, 19(3), 26-38. doi: 10.1109/ms.2002.1003450

Sarkar, M. B., Echambadi, R. a. J., \& Harrison, J. S. (2001). Alliance entrepreneurship and firm market performance. Strategic Management Journal, 22(6-7), 701-711. doi: 10.1002/smj.179

Schilling, M. A., \& Phelps, C. C. (2007). Interfirm collaboration networks: The impact of largescale network structure on firm innovation. Management Science, 53(7), 1113-1126. doi: $10.2307 / 20122273$

Schreiner, M., Kale, P., \& Corsten, D. (2009). What really is alliance management capability and how does it impact alliance outcomes and success? Strategic Management Journal, 30(13), 1395-1419. doi: 10.1002/smj.790

Schumpeter, J. A. (1954). History of economic analysis. Abingdon, United Kingdom: Routledge. Shan, W., \& Hamilton, W. (1991). Country-specific advantage and international cooperation. Strategic Management Journal, 12(6), 419-432. doi: 10.1002/smj.4250120603

Shieh, Y.-Y., \& Fouladi, R. T. (2003). The effect of multicollinearity on multilevel modeling parameter estimates and standard errors. Educational and Psychological Measurement, 63(6), 951-985. doi: 10.1177/0013164403258402

Shin, H.-H., \& Kim, Y. H. (2002). Agency costs and efficiency of business capital investment: Evidence from quarterly capital expenditures. Journal of Corporate Finance, 8(2), 139158. doi: 10.1016/S0929-1199(01)00033-5

Singer, J. D., \& Willett, J. B. (2003). Applied longitudinal data analysis: Modeling change and event occurrence. New York, New York: Oxford University Press, USA.

Sirmon, D. G., Hitt, M. A., Ireland, R. D. et al. (2011). Resource orchestration to create competitive advantage: Breadth, depth, and life cycle effects. Journal of Management, 37(5), 1390-1412. doi: 10.1177/0149206310385695

Speckbacher, G., Neumann, K., \& Hoffmann, W. H. (2015). Resource relatedness and the mode of entry into new businesses: Internal resource accumulation vs. Access by collaborative arrangement. Strategic Management Journal, 36(11), 1675-1687. doi: 10.1002/smj.2305

Starbuck, W. H., \& Mezias, J. M. (1996). Opening pandora's box: Studying the accuracy of managers' perceptions. Journal of Organizational Behavior, 17(2), 99-117.

Stevens, C. E., \& Shenkar, O. (2012). The liability of home: Institutional friction and firm disadvantage abroad. In Tihanyi L, Devinney TM, \& Pedersen T (Eds.), Institutional theory in international business and management (Vol. Advances in International Management). Bingley, United Kingdom: Emerald Group Publishing Limited.

Stevenson, H., H., \& Jarrillo-Mossi, J. C. (1986). Preserving entrepreneurship as companies grow. Journal of Business Strategy, 7(1), 10-23. doi: 10.1108/eb039138

Stevenson, H. H., \& Jarillo, J. C. (1990). A paradigm of entrepreneurship: Entrepreneurial management. Strategic Management Journal, 11, 17-27. 
Stuart, T., E., Hoang, H., \& Hybels, R. C. (1999). Interorganizational endorsements and the performance of entrepreneurial ventures. Administrative Science Quarterly, 44(2), 315349. doi: $10.2307 / 2666998$

Stuart, T. E. (2000). Interorganizational alliances and the performance of firms: A study of growth and innovation rates in a high-technology industry. Strategic Management Journal, 21(8), 791-811. doi: 10.1002/1097-0266(200008)21:8<791::aidsmj121>3.0.co;2-k

Stulz, R. M. (1990). Managerial discretion and optimal financing policies. Journal of Financial Economics, 26(1), 3-27. doi: 10.1016/0304-405X(90)90011-N

Subramaniam, M., \& Youndt, M. A. (2005). The influence of intellectual capital on the types of innovative capabilities. The Academy of Management Journal, 48(3), 450-463. doi: 10.5465/amj.2005.17407911

Szpiro, G. G. (1987). Hirschman versus herfindahl: Some topological properties for the use of concentration indexes. Mathematical Social Sciences, 14(3), 299-302. doi: 10.1016/01654896(87)90008-4

Tallman, S. B., \& Shenkar, O. (1994). International cooperative venture strategies: Outward investment and small firms from nics. Management International Review, 34, 75-91.

Teece, D. J., Pisano, G., \& Shuen, A. (1997). Dynamic capabilities and strategic management. Strategic Management Journal, 18(7), 509-533. doi: 10.1002/(sici)10970266(199708)18:7<509::aid-smj882>3.0.co;2-z

Thompson, B. (2006). Foundations of behavioral statistics: An insight-based approach. New York: Guilford Publications.

Thompson, J. D. (1967). Organizations in action: Social science bases of administrative theory. New York: McGraw-Hill.

Thuc Anh, P. T., Christopher Baughn, C., Minh Hang, N. T. et al. (2006). Knowledge acquisition from foreign parents in international joint ventures: An empirical study in vietnam. International Business Review, 15(5), 463-487. doi: 10.1016/j.ibusrev.2006.05.004

Tua, H. H. (2000). Difficulties in diffusion of tacit knowledge in organizations. Journal of Intellectual Capital, 1(4), 357-365. doi: 10.1108/14691930010359252

Uzzi, B. (1996). The sources and consequences of embeddedness for the economic performance of organizations: The network effect. American Sociological Review, 61(4), 674-698. doi: $10.2307 / 2096399$

Uzzi, B. (1997). Social structure and competition in interfirm networks: The paradox of embeddedness. Administrative Science Quarterly, 42(1), 35-67. doi: 10.2307/2393808

Van De Vrande, V., De Jong, J. P. J., Vanhaverbeke, W. et al. (2009). Open innovation in smes: Trends, motives and management challenges. Technovation, 29(6-7), 423-437. doi: 10.1016/j.technovation.2008.10.001

Verwaal, E., Commandeur, H., \& Verbeke, W. (2009). Value creation and value claiming in strategic outsourcing decisions: A resource contingency perspective. Journal of Management, 35(2), 420-444. doi: 10.1177/0149206308328502

Verwaal, E., \& Donkers, B. (2003). Customs-related transaction costs, firm size and international trade intensity. Small Business Economics, 21(3), 257-271. doi: 10.2307/40229291

Wasserman, S., \& Faust, K. (1994). Social network analysis: Methods and applications (Vol. 8). Cambrige, United Kingdom: Cambridge University Press.

West Iii, G. P., \& Bernhardt, J. N. (2009). An ascendant view of human resource management as a critical content dimension in new venture strategy. In Lumpkin GT, \& Katz JA (Eds.), 
Entrepreneurial strategic content (Vol. 11, pp. 103-135). Bingley, United Kingdom: Emerald Group Publishing Limited.

Williamson, O. E. (2008). Outsourcing: Transaction cost economics and supply chain management. Journal of Supply Chain Management, 44(2), 5-16. doi: 10.1111/j.1745493X.2008.00051.x

Winter, S. G., \& Szulanski, G. (2001). Replication as strategy. Organization Science, 12(6), 730743. doi: 10.1287/orsc.12.6.730.10084

Yan, A., \& Gray, B. (1994). Bargaining power, management control, and performance in united states-china joint ventures: A comparative case study. The Academy of Management Journal, 37(6), 1478-1517. doi: 10.2307/256796

Youndt, M. A., Snell, S. A., Dean, J. W., Jr. et al. (1996). Human resource management, manufacturing strategy, and firm performance. The Academy of Management Journal, 39(4), 836-866. doi: 10.2307/256714

Zahra, S. A., \& George, G. (2002). Absorptive capacity: A review, reconceptualization, and extension. The Academy of Management Review, 27(2), 185-203. doi: 10.5465/amr.2002.6587995

Zander, U., \& Kogut, B. (1995). Knowledge and the speed of the transfer and imitation of organizational capabilities: An empirical test. Organization Science, 6(1), 76-92. doi: 10.1287/orsc.6.1.76 
Table 1 - Descriptive Statistics and Correlation Matrix

\begin{tabular}{|c|c|c|c|c|c|c|c|c|c|c|c|c|c|c|c|c|c|c|c|c|}
\hline \# & Variable name & M & SD & VIF & 1 & 2 & 3 & 4 & 5 & 6 & 7 & 8 & 9 & 10 & 11 & 12 & 13 & 14 & 15 & 16 \\
\hline $\begin{array}{l}1 \\
2\end{array}$ & $\begin{array}{l}\text { Focal Firm Return on Assett } \\
\text { Related Alliance (3 Digits) }\end{array}$ & $\begin{array}{l}0.053 \\
0.352\end{array}$ & $\begin{array}{l}0.199 \\
0.478\end{array}$ & & $\begin{array}{c}1 \\
-0.024\end{array}$ & & & & & & & & & & & & & & & \\
\hline 3 & $\begin{array}{l}\text { Related Alliance (3 Digits) } \\
\text { International Alliance }\end{array}$ & 0.392 & 0.488 & $\begin{array}{l}1.998 \\
1.134\end{array}$ & $\begin{array}{r}-0.024 \\
0.040\end{array}$ & $\begin{array}{c}1 \\
-0.024 \\
\end{array}$ & 1 & & & & & & & & & & & & & \\
\hline 4 & $\begin{array}{l}\text { Multi-Partner Partnership } \\
\text { Pocl Firn Numen }\end{array}$ & 0.685 & 0.465 & 1.600 & 0.037 & $-0.159 * *$ & 0.018 & 1 & & & & & & & & & & & & \\
\hline $\begin{array}{l}5 \\
6\end{array}$ & $\begin{array}{l}\text { Focal Firm Number of Partners (In) } \\
\text { Firmer of }\end{array}$ & 1.376 & $\begin{array}{l}0.978 \\
0.597\end{array}$ & $\begin{array}{l}2.210 \\
1.654\end{array}$ & $\begin{array}{l}0.150^{* *} \\
0109^{* *}\end{array}$ & $\begin{array}{l}-0.217^{* *} \\
0.061 *\end{array}$ & $\begin{array}{l}0.084^{* *} \\
0.065 *\end{array}$ & $\begin{array}{l}0.458^{* *} \\
-0.006\end{array}$ & 1 & & & & & & & & & & & \\
\hline $\begin{array}{l}6 \\
7\end{array}$ & $\begin{array}{l}\text { Focal Firm Available Slack (ln) } \\
\text { Focal Firm Hirschan Inde }\end{array}$ & $\begin{array}{r}0.630 \\
-0.374\end{array}$ & 0.597 & $\begin{array}{l}1.654 \\
1.296\end{array}$ & $\begin{array}{l}0.109^{* *} \\
-0.258^{* *}\end{array}$ & $0.061^{*} * *$ & $\begin{array}{c}0.065^{*} \\
-0.092 * *\end{array}$ & -0.006 * & $-0.104^{* *} *$ & $\begin{array}{c}1 \\
0.66 *\end{array}$ & & & & & & & & & & \\
\hline 8 & $\begin{array}{l}\text { Focal Firm Hirschman Index } \\
\text { Focal Firm OC (ln) }\end{array}$ & $\begin{array}{l}-0.374 \\
-1251\end{array}$ & 0.241 & $\begin{array}{l}1.296 \\
1.865\end{array}$ & $=0.258^{* *}$ & $0.084^{* *} *$ & $-0.092^{* *}$ & $0.061^{*}$ & $-0.238^{* *} *$ & $0.060^{*} * *$ & $\begin{array}{c}1 \\
-0075 * *\end{array}$ & & & & & & & & & \\
\hline 9 & $\begin{array}{l}\text { Focal irm OC (In) } \\
\text { Focal Firm Financial PFR (ln) }\end{array}$ & $\begin{array}{l}-1.251 \\
-1.305\end{array}$ & $\begin{array}{l}0.638 \\
1.066\end{array}$ & $\begin{array}{l}1.805 \\
2.482\end{array}$ & $\begin{array}{l}-0.218^{* *} \\
0.063^{*}\end{array}$ & $\begin{array}{l}0.084^{* 4} \\
0.050\end{array}$ & $0.1175^{* *}$ & $\begin{array}{r}0.014 \\
-0.030\end{array}$ & $\begin{array}{l}0.011 \\
0.011\end{array}$ & $0.574^{* *}$ & $\begin{array}{l}-0.077^{* a} \\
-0.037\end{array}$ & $0.609 * *$ & & & & & & & & \\
\hline 10 & Focal Firm Labor PFR (ln) & -12.572 & 0.841 & 1.270 & $-0.184^{* *}$ & $0.060^{*}$ & $0.061^{*}$ & 0.009 & $-0.239 * *$ & $0.172^{* *}$ & $0.240^{* *}$ & $0.080^{* *}$ & $0.116^{* *}$ & 1 & & & & & & \\
\hline 11 & Partner Firm OC (ln) & $\begin{array}{r}-1.350 \\
-576\end{array}$ & 0.822 & 1.620 & $-0.108^{* *}$ & $0.241^{* *} *$ & 0.018 & $-0.106^{* *} *$ & $-0.172^{* * *}$ & $0.080^{* *}$ & 0.045 & $0.228^{* *}$ & $0.171 * *$ & $-0.088^{* *}$ & & & & & & \\
\hline 12 & Partner Firm Financial PFR (In) & -1.576 & 1.258 & $\begin{array}{l}1.558 \\
3526\end{array}$ & 0.003 . & $0.224^{* *}$ & 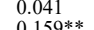 & $\begin{array}{l}-0.1177^{* *} \\
050 \% *\end{array}$ & $-0.160^{* *}$ & $0.074^{* *}$ & -0.004 & $0.072^{*}$ & $0.134^{* *}$ & $-0.165^{* *}$ & $0.507^{* *} *$ & 1 & & & & \\
\hline 14 & 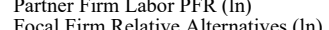 & 8.042 & 2.589 & $\begin{array}{l}3.526 \\
2020\end{array}$ & $\begin{array}{l}0.183^{* *} \\
0.096 *\end{array}$ & $-0.348^{* *} * *$ & $0.159^{* *} *$ & $\begin{array}{l}0.509^{* *} \\
0.078^{* *}\end{array}$ & $0.521^{* *} *$ & 0.019 & $-0.095^{* *}$ & -0.006 & -0.023 & -0.032 & $-0.291 * *$ & $\begin{array}{l}-0.315 * * \\
0.113 * *\end{array}$ & $\frac{0.003}{1}$ & & & \\
\hline 15 & Focal Firm Relative Profitability & 0.048 & 0.281 & $\begin{array}{l}2.020 \\
1.242\end{array}$ & $0.603 * *$ & $0.078^{* *}$ & 0.006 & -0.044 & -0.017 & $0.133^{* *}$ & $\begin{array}{l}-0.050 \\
-0.050\end{array}$ & $-0.091^{* *}$ & $0.109 * *$ & $\begin{array}{l}-0.090 * * \\
-0.154 * *\end{array}$ & $0.069^{*} * *$ & $0.154 * *$ & $-0.09 * *$ & 0015 & & \\
\hline 16 & $\begin{array}{l}\text { Focal Firm Relative Size } \\
\text { File }\end{array}$ & 0.099 & 0704 & 2.847 & $0071 *$ & $0.228^{* *}$ & 0.009 & $-0.46^{* *}$ & $-01188^{* * *}$ & $-0131 * *$ & $-0216 * *$ & -0.03 & -0.018 & $-0.073^{*} *$ & $0.191 * *$ & $0.289 * *$ & $-0703 * *$ & $0.104^{*} *$ & $171 * *$ & 1 \\
\hline
\end{tabular}

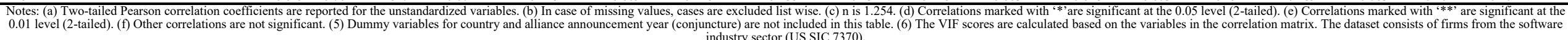


Table 2 - Hierarchical Linear Fixed Effects Model (HLM)

\begin{tabular}{|c|c|c|c|c|c|c|c|}
\hline $\begin{array}{l}\text { Dependent variable: } \\
\text { Return on Assets // US SIC } 7370\end{array}$ & Model 1 & Model 2 & Model 3 & Model 4 & Model 5 & Model 6 & Model 7 \\
\hline \multicolumn{8}{|l|}{ Explanatory variables } \\
\hline Partner Firm OC (ln) (H1a) & & $\begin{array}{l}-0.05 * * * \\
(0.01)\end{array}$ & $\begin{array}{l}-0.05 * * * \\
(0.01)\end{array}$ & $\begin{array}{l}-0.02 * \\
(0.01)\end{array}$ & $\begin{array}{l}-0.01 \\
(0.01)\end{array}$ & $\begin{array}{l}-\mathbf{0 . 0 1} \\
(\mathbf{0 . 0 1})\end{array}$ & $\begin{array}{l}-0.01 \\
(0.01)\end{array}$ \\
\hline Partner Firm Financial PFR (In) (H2a) & & $\begin{array}{l}0.03 * * * \\
(0.01)\end{array}$ & $\begin{array}{l}0.03 * * * \\
(0.01)\end{array}$ & $\begin{array}{l}0.02 * \\
(0.01)\end{array}$ & $\begin{array}{c}0.00 \\
(0.01)\end{array}$ & $\begin{array}{l}-0.01 \\
(0.01)\end{array}$ & $\begin{array}{c}0.01 \\
(0.01)\end{array}$ \\
\hline Partner Firm Labor PFR (ln) (H2b) & & $\begin{array}{l}0.04 * * * \\
(0.01)\end{array}$ & $\begin{array}{l}0.06 * * * \\
(0.01)\end{array}$ & $\begin{array}{l}0.06 * * * * \\
(0.01)\end{array}$ & $\begin{array}{l}0.04 * * * \\
(0.01)\end{array}$ & $\begin{array}{l}0.04 * * * \\
(0.01)\end{array}$ & $\begin{array}{l}0.03 * * * \\
(0.01)\end{array}$ \\
\hline Focal Firm Relative Alternatives (ln) & & $\begin{array}{r}0.01 \dagger \\
(0.01)\end{array}$ & $\begin{array}{l}0.01 \\
(0.01)\end{array}$ & $\begin{array}{l}0.01 \\
(0.01)\end{array}$ & $\begin{array}{l}0.01 \dagger \\
(0.01)\end{array}$ & $\begin{array}{l}0.02 * \\
(0.01)\end{array}$ & $\begin{array}{r}0.01 \dagger \\
(0.01)\end{array}$ \\
\hline Focal Firm Relative Profitability & & $\begin{array}{l}0.12 * * * \\
(0.00)\end{array}$ & $\begin{array}{l}0.12 * * * \\
(0.00)\end{array}$ & $\begin{array}{l}0.12 * * * \\
(0.00)\end{array}$ & $\begin{array}{l}0.14 * * * \\
(0.00)\end{array}$ & $\begin{array}{l}0.16^{* * * *} \\
(0.00)\end{array}$ & $\begin{array}{l}0.16 * * * \\
(0.00)\end{array}$ \\
\hline Focal Firm Relative Size & & & $\begin{array}{l}0.03 * * * \\
(0.01)\end{array}$ & $\begin{array}{l}0.03 * * * \\
(0.01)\end{array}$ & $\begin{array}{l}0.02 * * \\
(0.01)\end{array}$ & $\begin{array}{l}0.02 * * \\
(0.01)\end{array}$ & $\begin{array}{l}0.02 * * \\
(0.01)\end{array}$ \\
\hline $\begin{array}{l}\text { International Alliance * Related Alliance } \\
\text { ( } 3 \text { Digits) }\end{array}$ & & & & $\begin{array}{c}0.00 \\
(0.03)\end{array}$ & $\begin{array}{c}0.02 \\
(0.03)\end{array}$ & $\begin{array}{c}0.03 \\
(0.02)\end{array}$ & $\begin{array}{c}0.03 \\
(0.02)\end{array}$ \\
\hline $\begin{array}{l}\text { Partner Firm OC }(\ln ) * \text { Related Alliance } \\
\text { (3 Digits) }\end{array}$ & & & & $\begin{array}{l}-0.06^{* * * *} \\
(0.01)\end{array}$ & $\begin{array}{l}-0.05 * * * \\
(0.01)\end{array}$ & $\begin{array}{l}-0.04 * * \\
(0.01)\end{array}$ & $\begin{array}{l}-0.05 * * * \\
(0.01)\end{array}$ \\
\hline Partner Firm Financial PFR (ln) * Related & & & & $0.06 * * *$ & $0.06 * * *$ & $0.06^{* * * *}$ & $0.06 * * *$ \\
\hline Alliance (3 Digits) & & & & $(0.01)$ & $(0.01)$ & $(0.01)$ & $(0.01)$ \\
\hline Partner Firm Labor PFR (ln) * Related & & & & $\begin{array}{c}0.02 \\
(0.02)\end{array}$ & $\begin{array}{c}0.01 \\
(0.02)\end{array}$ & $\begin{array}{c}0.00 \\
(0.02)\end{array}$ & $\begin{array}{c}0.02 \\
(0.02)\end{array}$ \\
\hline Partner Firm OC $(\ln ) *$ International & & & & -0.01 & -0.02 & $-0.02 \div$ & $-0.02 \dagger$ \\
\hline Alliance & & & & $(0.01)$ & $(0.01)$ & $(0.01)$ & $(0.01)$ \\
\hline Partner Firm Financial PFR (ln) * & & & & -0.02 & 0.00 & 0.00 & 0.00 \\
\hline International Alliance & & & & $(0.01)$ & $(0.01)$ & $(0.01)$ & $(0.01)$ \\
\hline Partner Firm Labor PFR (ln) * & & & & -0.01 & 0.00 & 0.01 & 0.00 \\
\hline International Alliance & & & & $(0.01)$ & $(0.01)$ & $(0.01)$ & $(0.01)$ \\
\hline Focal Firm Relative Alternatives $(\ln ) *$ & & & & & 0.00 & 0.00 & 0.00 \\
\hline Focal Firm Relative Profitability & & & & & $(0.00)$ & $(0.00)$ & $(0.00)$ \\
\hline Focal Firm Relative Alternatives (ln) * & & & & & 0.01 & 0.01 & 0.01 \\
\hline Focal Firm Relative Size & & & & & $(0.01)$ & $(0.01)$ & $(0.01)$ \\
\hline Focal Firm Relative Profitability * Focal & & & & & $-0.06 * * *$ & $-0.05 * * *$ & $-0.05 * * *$ \\
\hline Firm Relative Size & & & & & $(0.00)$ & $(0.00)$ & $(0.00)$ \\
\hline Partner Firm OC $(\ln ) *$ Focal Firm & & & & & $0.02 * *$ & $0.01 *$ & $0.01 *$ \\
\hline Relative Alternatives $(\ln )$ & & & & & $(0.01)$ & $(0.01)$ & $(0.01)$ \\
\hline Partner Firm Financial PFR $(\ln ) *$ Focal & & & & & $-0.02 *$ & $-0.01 *$ & $-0.01 *$ \\
\hline Firm Relative Alternatives (ln) & & & & & $(0.01)$ & $(0.01)$ & $(0.01)$ \\
\hline Partner Firm Labor PFR (ln) * Focal Firm & & & & & -0.01 & -0.01 & -0.01 \\
\hline Relative Alternatives (ln) & & & & & $(0.01)$ & $(0.01)$ & $(0.01)$ \\
\hline Partner Firm OC $(\ln ) *$ Focal Firm & & & & & & $-0.02 * * *$ & $-0.02 * * *$ \\
\hline Relative Profitability & & & & & & $(0.00)$ & $(0.00)$ \\
\hline Partner Firm Financial PFR $(\ln ) *$ Focal & & & & & & $0.03 * * *$ & $0.03 * * *$ \\
\hline Firm Relative Profitability & & & & & & $(0.00)$ & $(0.00)$ \\
\hline Partner Firm Labor PFR (ln) * Focal Firm & & & & & & $0.02 * *$ & $0.02 * * *$ \\
\hline Relative Profitability & & & & & & $(0.01)$ & $(0.01)$ \\
\hline Partner Firm OC (ln) * Focal Firm & & & & & & & $0.02 * * *$ \\
\hline Relative Size (H1b) & & & & & & & $(\mathbf{0 . 0 1})$ \\
\hline Partner Firm Financial PFR (ln) * & & & & & & & $-0.03 * * *$ \\
\hline Focal Firm Relative Size (H2c) & & & & & & & $(0.01)$ \\
\hline Partner Firm Labor PFR (ln) * Focal & & & & & & & $-0.02 * * *$ \\
\hline Firm Relative Size (H2d) & & & & & & & $(0.01)$ \\
\hline \multirow[t]{2}{*}{ Related Alliance (3 Digits) } & 0.02 & 0.01 & 0.01 & 0.01 & 0.00 & -0.01 & 0.00 \\
\hline & $(0.02)$ & $(0.02)$ & $(0.02)$ & $(0.02)$ & $(0.02)$ & $(0.02)$ & $(0.02)$ \\
\hline \multirow[t]{2}{*}{ International Alliance } & 0.01 & -0.01 & -0.01 & -0.01 & -0.02 & -0.02 & -0.02 \\
\hline & $(0.02)$ & $(0.01)$ & $(0.01)$ & $(0.02)$ & $(0.01)$ & $(0.01)$ & $(0.01)$ \\
\hline \multirow[t]{2}{*}{ Multi-Partner Partnership } & -0.01 & $-0.03 \dagger$ & -0.02 & -0.02 & -0.01 & -0.01 & 0.00 \\
\hline & $(0.02)$ & $(0.02)$ & $(0.02)$ & $(0.02)$ & $(0.01)$ & $(0.01)$ & $(0.01)$ \\
\hline \multirow[t]{2}{*}{ Focal Firm Number of Partners (ln) } & $0.02 *$ & 0.01 & 0.00 & 0.00 & -0.01 & -0.01 & -0.01 \\
\hline & $(0.01)$ & $(0.01)$ & $(0.01)$ & $(0.01)$ & $(0.01)$ & $(0.01)$ & $(0.01)$ \\
\hline \multirow[t]{2}{*}{ Focal Firm Available Slack (ln) } & $0.02 *$ & 0.01 & 0.01 & 0.01 & 0.01 & 0.01 & 0.01 \\
\hline & $(0.01)$ & $(0.01)$ & $(0.01)$ & $(0.01)$ & $(0.01)$ & $(0.01)$ & $(0.01)$ \\
\hline \multirow[t]{2}{*}{ Focal Firm Industry Diversification (ln) } & $-0.03 * * *$ & $-0.03 * * *$ & $-0.02 * * *$ & $-0.02 * * *$ & $-0.02 * * *$ & $-0.01 * *$ & $-0.02 * * *$ \\
\hline & $(0.01)$ & $(0.00)$ & $(0.00)$ & $(0.00)$ & $(0.00)$ & $(0.00)$ & $(0.00)$ \\
\hline
\end{tabular}


Focal Firm OC (ln)

Focal Firm Financial PFR (ln)

Focal Firm Labor PFR (ln)

Intercept

Number of Firm-Years

Number of Firms

-2 Maximum Log Likelihood

Adjusted $\Delta-2 \mathrm{LL}$

$\mathrm{R}$ Squared

$-0.09^{* * *}$
$(0.01)$
$0.06^{* * *}$
$(0.01)$
$-0.02 *$
$(0.01)$
$0.07 *$
$(0.03)$
1730.00
273.00
-1403.41

0.2423

0.2423
$-0.07 * * *$

$(0.01)$

$0.04 * * *$

$(0.01)$

$-0.02 * *$

$(0.01)$

0.04

$(0.02)$

1254.00

218.00

$-1884.70$

$481.29 * * *$ 0.5737
$-0.06 * * *$

$(0.01)$

$0.04 * * *$

$(0.01)$

$-0.02 * *$

$(0.01)$

0.03

$(0.02)$

1254.00

218.00

$-1897.45$

$12.75^{* * *}$ 0.5891
$-0.06 * * *$
$(0.01)$

$0.04 * * *$

$(0.01)$

$-0.02 * *$

$(0.01)$

0.03

(0.02)

12540.00

218.00

$-1928.71$

$31.26^{* * *}$

0.6052

$-0.05 * * *$
$(0.01)$
$0.03 * * *$
$(0.01)$
$-0.02 * * *$
$(0.01)$
$0.05 *$
$(0.02)$
1254.00
218.00
-2277.79
$349.08 * * *$
0.6999

$-0.05 * * *$

(0.01)

$-0.05^{* * *}$

$(0.01)$

$0.02 * * * \quad 0.02 * * *$

$(0.01) \quad(0.01)$

$-0.03 * * * \quad-0.03 * * *$

$(0.01) \quad(0.01)$

$0.05 * \quad 0.04 \dagger$

$(0.02) \quad(0.02)$

$1254.00 \quad 1254.00$

$218.00 \quad 218.00$

$\begin{array}{lr}-2354.54 & -2392.49\end{array}$

$76.75 * * * \quad 37.95 * * *$

0.7127

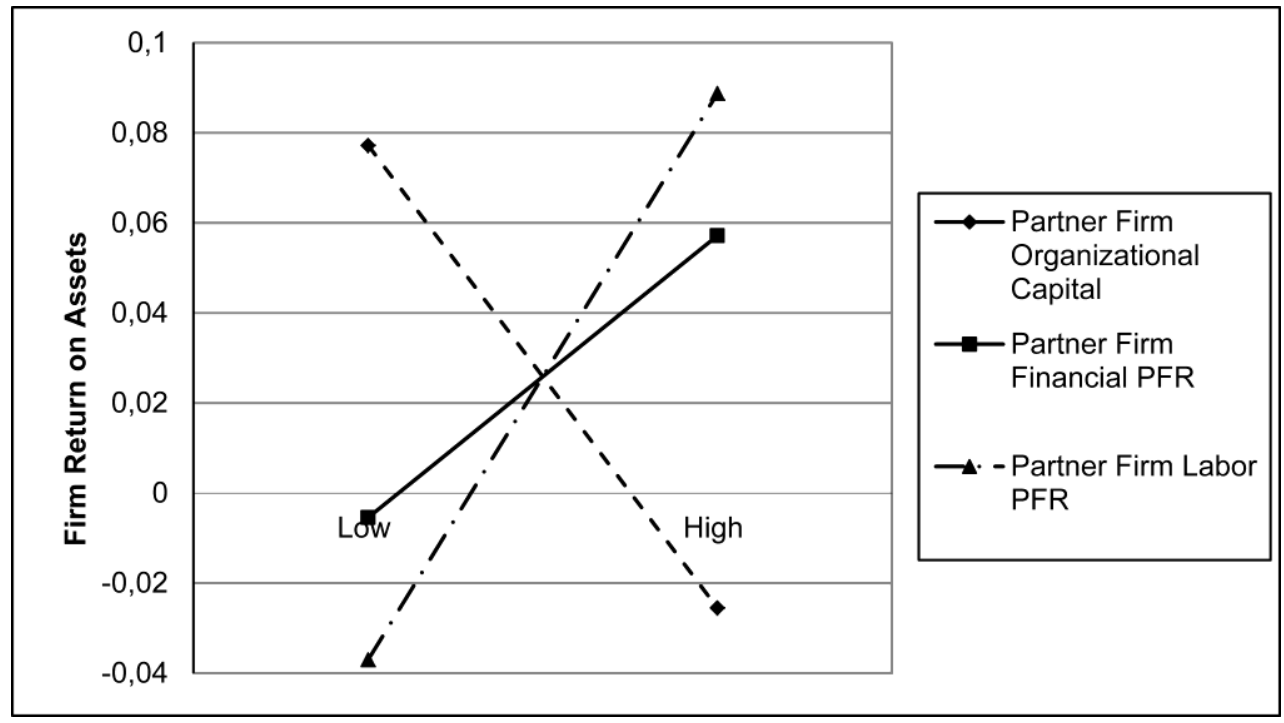

Fig.1 Focal firm financial performance effects as result of partner firm OC, financial PFR, and labor PFR (Model 3)
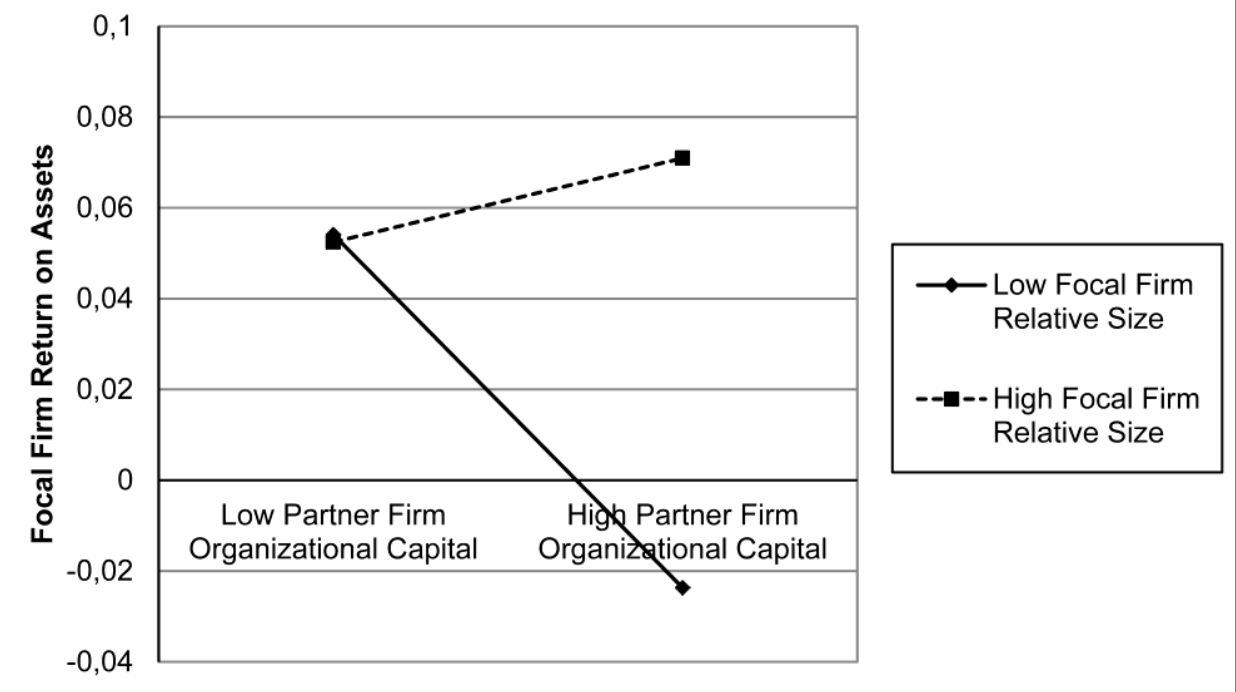

Fig. 2 Focal firm financial performance effects as result of the interaction between partner firm OC and the focal firm relative size (Model 7) 


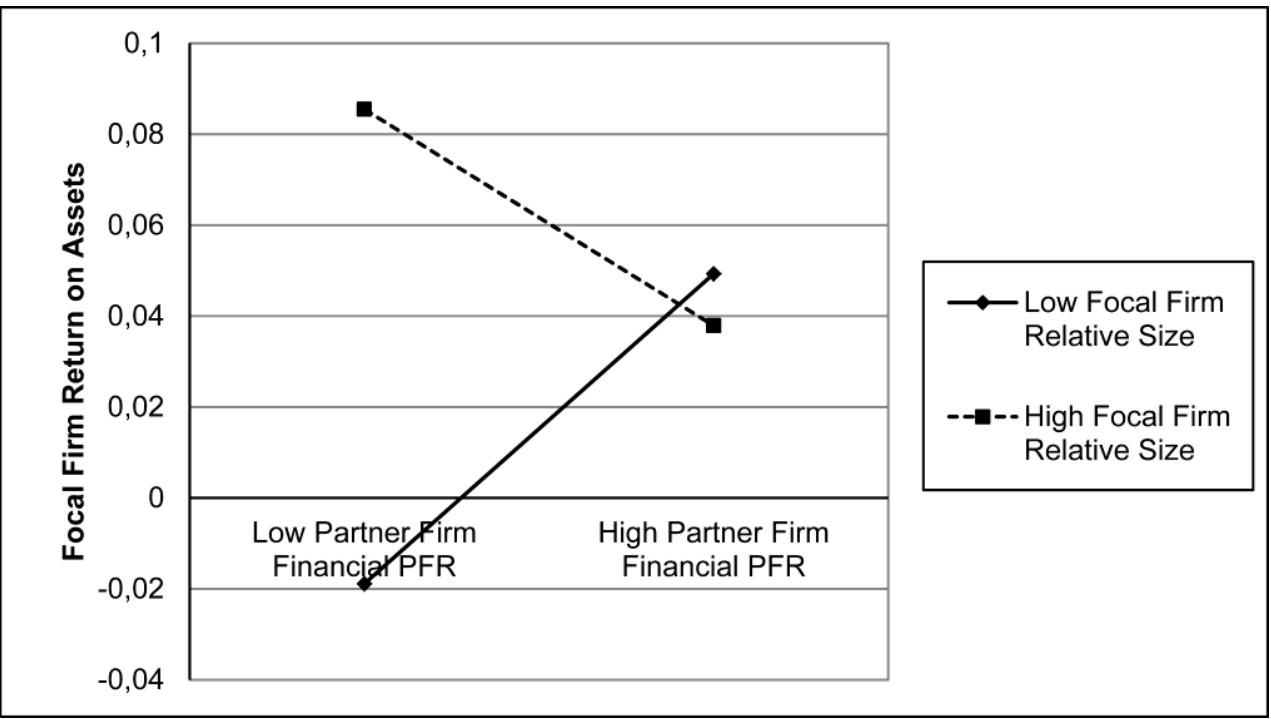

Fig. 3 Focal firm financial performance effects as result of the interaction between partner firm financial PFR and focal firm relative size (Model 7)

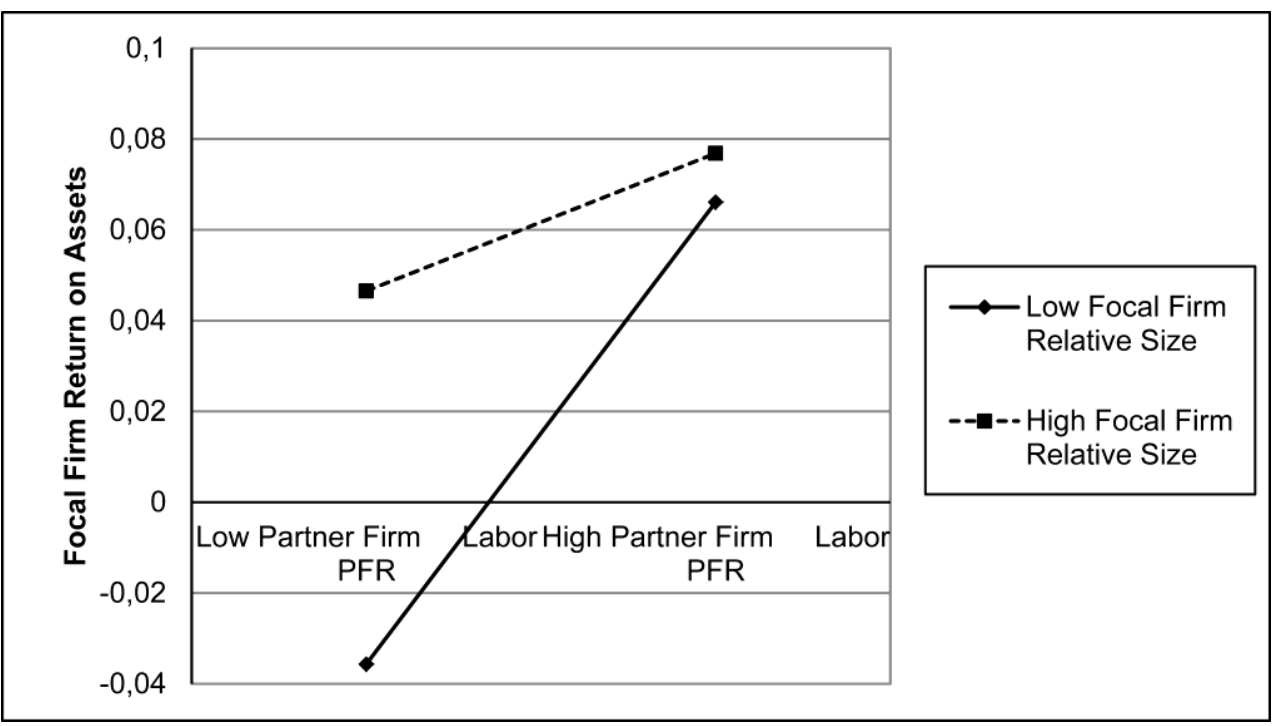

Fig. 4 Focal firm financial performance effects as result of the interaction between partner firm labor PFR and focal firm relative size (Model7) 